\title{
Theoretical Investigations on Potential Impacts of High-Latitude Volcanic Emissions of Heat, Aerosols and Water Vapor and their Interactions with Clouds and Precipitation
}

\author{
Morgan B. Yarker ${ }^{1}$, Debasish PaiMazumder ${ }^{1}$, Catherine F. Cahill ${ }^{2}$, Jonathan Dehn ${ }^{3}$, Anupma Prakash ${ }^{4}$ \\ and Nicole Mölders ${ }^{*}, 1$
}

\author{
${ }^{I}$ University of Alaska Fairbanks, Geophysical Institute \& College of Natural Science and Mathematics, Department of \\ Atmospheric Sciences, 903 Koyukuk Dr., Fairbanks, Alaska 99775, USA \\ ${ }^{2}$ University of Alaska Fairbanks, Geophysical Institute \& Department of Chemistry and Biochemistry, 903 Koyukuk Dr., \\ Fairbanks, Alaska 99775, USA \\ ${ }^{3}$ University of Alaska Fairbanks, Geophysical Institute \& Alaska Volcano Observatory, 903 Koyukuk Dr., Fairbanks, \\ Alaska 99775, USA \\ ${ }^{4}$ University of Alaska Fairbanks, Geophysical Institute \& Department of Geophysics, 903 Koyukuk Dr., Fairbanks, \\ Alaska 99775, USA
}

\begin{abstract}
Augustine Volcano (located in the Cook Inlet of South Central Alaska at $59.4^{\circ} \mathrm{N}$ and $153.4^{\circ} \mathrm{W}$ ) erupted in January 2006 and released, among other things, water vapor, radiation heat, and aerosols into the atmosphere. To determine the potential impact of volcanic emissions and ashfall on local weather, 16 simulations assuming artificial emission and ashfall scenarios were performed with the Weather Research and Forecasting model for 24 consecutive days starting the day before the first eruption. These simulations include (1) the control simulation without consideration of any volcanic perturbation, (2) four simulations with simplified scenarios for each individual volcanic factor [radiative heat from the caldera, water vapor, cloud condensation nuclei $(\mathrm{CCN})$ and/or ice nuclei (IN) aerosols, and albedo change due to ashfall], and (3) 11 simulations containing all possible combinations of these factors. These 11 simulations serve to examine interactions among impacts of the different perturbations under the assumed scenarios. The impact of volcanic factors on local weather depends on the synoptic situation, emission strength, (combination of) volcanic factors, and interaction among impacts of factors if they occur concurrently. ANalysis Of VAriance shows that the greatest (statistically significant at the $95 \%$ or higher confidence level) volcanic impact occurs on relatively humid days and immediately downwind of the volcano $(<50 \mathrm{~km})$. Depending on relative humidity and temperature conditions, volcanic heat release can increase condensation and/or cloud top levels or reduce cloudiness. Due to non-linear cloud microphysical processes, meteorological responses to volcanic factors can diminish or enhance the impacts of the individual factors when factors occur concurrently. As an example, depending on the ambient conditions, concurrently occurring volcanic factors can lead to a decrease in precipitation at one time and an increase at another time. These findings indicate that in the immediate vicinity of erupting volcanoes, predicted cloud conditions and precipitation may be inaccurate due to the unknown volcanic forcing.
\end{abstract}

Keywords: Volcanic emissions, WRF, ANOVA, clouds, evaluation.

\section{INTRODUCTION}

Volcanic eruptions, regardless of intensity and duration, can affect the atmosphere, regional weather, and regional and global climate via various paths (Fig. 1) [1-7]. A direct effect of volcanic aerosols on the atmosphere results from their scattering and absorbing of radiation in large parts of the spectrum. Hygroscopic ash particles injected into the troposphere increase the number and spectra of condensation nuclei $(\mathrm{CCN})$ and/or ice nuclei (IN). More $\mathrm{CCN}$ and IN

*Address correspondence to this author at the University of Alaska Fairbanks, Geophysical Institute \& College of Natural Science and Mathematics, Department of Atmospheric Sciences, 903 Koyukuk Dr., Fairbanks, Alaska 99775, USA; Tel: (907) 474-7910; Fax: (907) 474-7379;

E-mail: molders@gi.alaska.edu compete for excess water vapor under saturated conditions. Smaller, but more cloud droplets form [8-10] for which cloud lifetime increases. The impact of additional IN can go two ways. Meteorological clouds are typically IN-limited so that additional IN from volcanic eruptions can lead to "overseeding" resulting in enhanced ice particle concentrations, reduced ice-particle sizes and prolonged cloud lifetimes; Compared to dynamically similar meteorological clouds, glaciation may occur over a relatively narrow altitude range [11]. The reduced cloud-droplet and ice-crystal sizes not only diminish coalescence and riming (aka the riming-indirect effect), thereby decreasing precipitation formation efficiency, but also result in enhanced cloud albedo (aka the Twomey effect). Cloud albedo enhancement and modified cloud lifetime are referred to as indirect aerosol effects. 


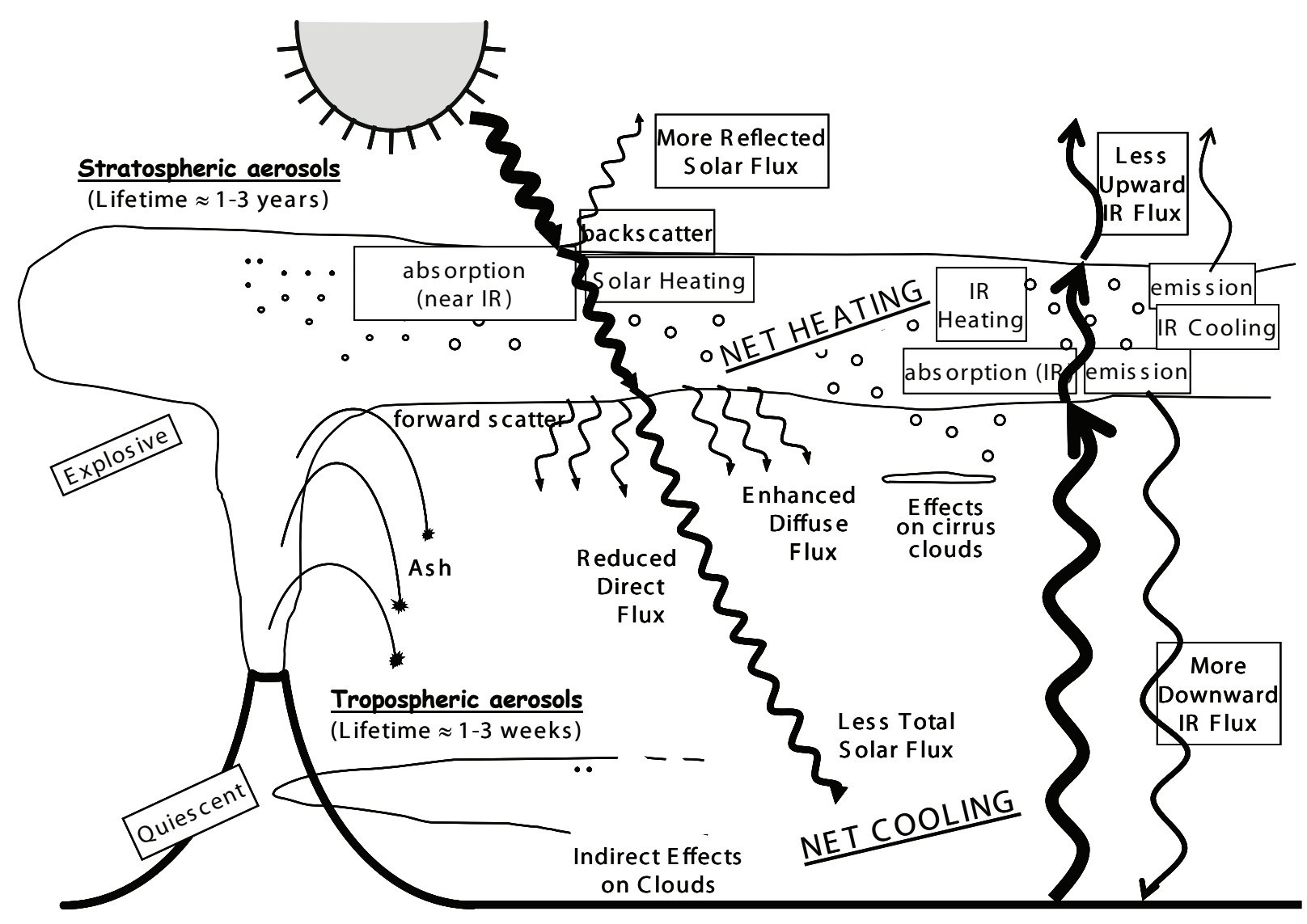

Fig. (1). Schematic view of potential physical effects of volcanic eruptions on both global and regional climate via various physical paths. Simplified after [18].

The other way additional IN may influence precipitation is that more IN may increase the efficiency of precipitation formation via the glaciation indirect aerosol effect. Due to the lower saturation vapor pressure over ice than water, ice crystals grow at the expense of cloud droplets in mixed phase clouds (aka the Findeisen-Bergeron-Wegener process).

Reduced cloud-droplet sizes delay freezing leading to thermodynamic effects [12]. Thermodynamic effects of phase changes contribute to the total thermal energy within the cloud and considerably affect buoyancy [13], a process commonly referred to as interaction microphysics-dynamics [14].

A semi-direct effect of volcanic aerosols is associated with absorption of solar radiation that can cause evaporation/sublimation of liquid and solid cloud particles [15]. The increased aerosol amount and cloud optical thickness affect net surface solar radiation (aka the surfaceenergy budget effect). Volcanic aerosols injected into the stratosphere scatter some of the incoming solar radiation back to space which results in surface cooling [7, 10]. Volcanic aerosols transported back into the troposphere increase high-level cloudiness and cloud persistence $[12,16]$ that impact the radiation budget. The eruptions of Mt. St. Helen, Pinatubo, Okmok and Kasatochi led to reduced incoming solar radiation and cooling underneath the ash clouds [15]. On the local scale, volcanic aerosols in the troposphere cause daytime surface cooling by reflecting sunlight to space, and nighttime surface warming by infrared emission downward to the surface. This infrared effect causes increased air temperatures and evaporation and/or sublimation of cloud particles. The infrared effect also works during daytime, but is larger at nighttime when no solar radiation is available. Also on the local scale, ashfall over snow-covered surfaces decreases surface albedo leading to reduced reflection of incoming solar radiation and increased near-surface air temperatures. Ashfall over forests, for instance, can increase albedo and hence have the opposite effect on near-surface air temperatures.

How volcanic aerosols affect atmospheric dynamics depends on the location of injection. Large explosive eruptions in the Tropics affect the tropospheric general circulation via forcing from differential stratospheric heating $[3,5,17,18]$ and increase the land-sea temperature gradient [3]. Volcanic aerosols injected into the Arctic stratosphere can modify the zonal winds through the warming related to absorption [3]. Long-range transport then may lead to further impacts in mid and low latitudes regions $[3,19]$.

After large volcanic eruptions tropospheric water vapor decreases due to water vapor feedback which enhances cooling [20]. Radiation from lava that heats the near-surface 
air and produces air parcels that are warmer than the environment may affect local atmospheric buoyancy. The hot air ascends until the kinetic and thermal energy plus latent heat release from condensation/water vapor deposition equals the work performed to increase potential energy. Volcanic aerosols and water vapor rapidly ascend until the level of neutral buoyancy is reached. Heat and emissions from Pinatubo, for instance, were found to increase convection and determine the timing of the diurnal peak of convection over the area [21].

Due to the complexity and hugely contrasting spatial and temporal scales associated with volcanic eruptions, a single model cannot encompass all relevant processes [22]. Therefore, scientists have developed various different models to examine volcanic eruptions and/or their impact on the atmosphere. Typically, these models focus on one temporal and spatial scale to investigate a specific aspect of the volcanic effects on or within the atmosphere [22]. Modular and generic models, for instance, simulate atmospheric dispersal of the erupted gas-particle mixture in the immediate environment of the volcano [23]. These models consider the rapid processes occurring in the plume and lower convective region, pyroclastic density currents, and the sedimentation and ash dispersal from those flows. On a small scale, the latent heat from volcanic eruptions strongly affects plume dynamics. To capture the bulk characteristics of the plume (plume height, horizontal extent, plume development) in time, turbulence parameterization schemes are required that differentiate between horizontal and vertical turbulent exchange to represent the strong influence of buoyancy forces and vertical transports; anisotropic effects of turbulence influence the stability and internal structure of the plume significantly [24]. Ashtracking models have been used for predicting the long-range dispersion of volcanic ash clouds to prevent ash-aircraft interactions [25]. General circulation models (GCMs) are used to examine the climate impact of volcanic eruptions [12]. GCM studies show that large eruptions have long-term global impacts on circulation patterns e.g., [5, 26-28].

Various climate and mesoscale studies showed that due to various feedback mechanisms, high latitudes are very sensitive to even slight changes in surface albedo, water vapor, temperature, radiative forcing and aerosol concentration e.g. [29-31]. The Aleutian Islands in Alaska make up the high-latitude northern part of the Ring of Fire. This high-latitude region of strong volcanic activity exists in a climate zone with strong storm activity and frequent occurrence of mixed phase clouds and where medical supply and transportation strongly depend on airplanes. Consequently, air traffic limitations due to volcanic eruptions and volcanic influences on local weather may have huge consequences for aviation and economics. The January 2006 eruption of Augustine Volcano, for instance, released an ash plume into the atmosphere [32] that caused cancellation or diversion of nearly two dozen flights. The Redoubt eruption in 1989 caused an aircraft's engines to stop working [33].

Planning flight routes relies on weather forecasts. Due to Alaska's strong dependence on aviation and large number of volcanoes, it is important to examine how reliable weather forecasts are during eruptions. Such investigation is also required because operational numerical weather prediction (NWP) serve to drive ash-tracking models to assess the potential for aviation safety. Thus, the goals of our study are to investigate: (1) the complex interaction between the effects of volcanic emission of radiative heat, water vapor and aerosols, and volcanic ashfall, (2) the short-term impacts of volcanic emissions on local weather, and (3) how far away from the volcano, moderate eruptions may affect clouds and precipitation.

\section{METHOD AND EXPERIMENTAL DESIGN}

Theoretical exploration of the impacts of volcanic emissions and their interaction on clouds and precipitation requires a meso- $\beta$-scale NWP model modified for inclusion of volcanic effects. This model must be able to address a scale larger than the proximal and distal environment of models developed specifically for the simulation of plume dynamics, but smaller than the regional/synoptic (meso- $\alpha$ ) scale of ash-tracking models [22]. Thus, we use a modified version of the Weather Research and Forecasting model WRF; [34]. The modifications described later serve to include volcanic perturbations.

\subsection{Model Set-Up and Modifications}

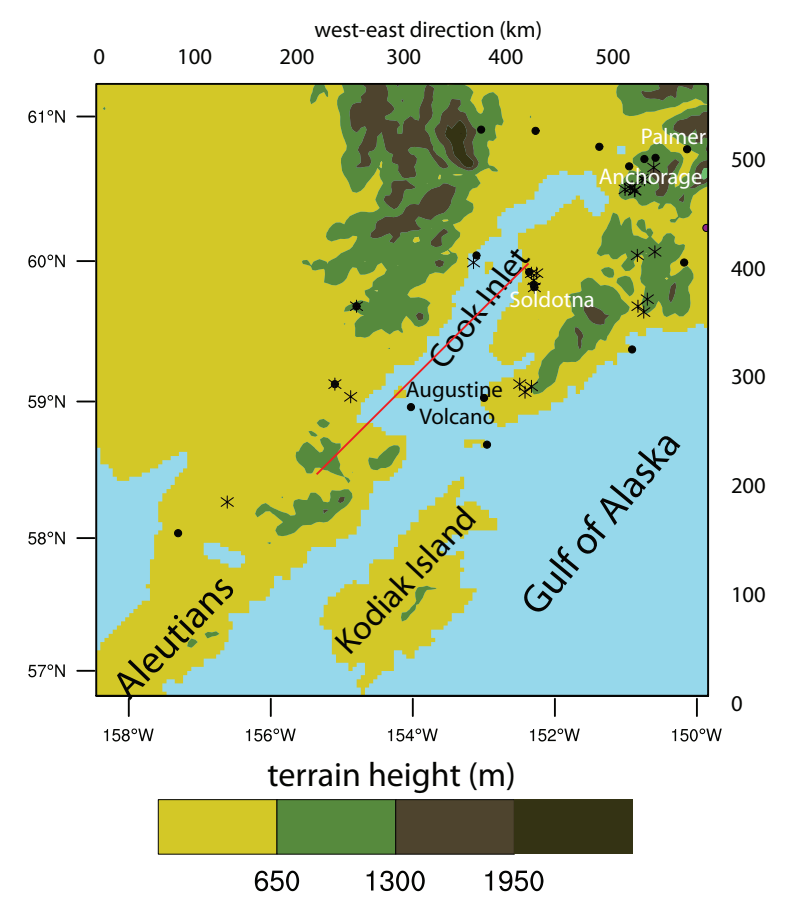

Fig. (2). Terrain height, location of sites with hourly (dots) and daily observations (asterisks) used in the evaluation, and the cross section shown in Figs. (5-10). The model domain encompasses 355,216 square-kilometers. For orientation with respect to distances given in the text, the horizontal extension of the domain is given at the on the eastern and northern boundaries of the model domain. For a broad idea of the location of the model domain the longitudes of the southern and the latitudes of the western boundaries of the model domain are given. Note that for a rectangular grid with $4 \mathrm{~km}$ grid increment the longitude lines are not parallel, i.e. they are different at the southern boundary of the domain. Augustine Volcano is located in the center of the domain at $59.4^{\circ} \mathrm{N}, 153.4^{\circ} \mathrm{W}$. Names refer to locations mentioned in the text. Names of cities are in white. 
The model domain encompasses $149 \times 149$ grid points in the horizontal directions with $4 \mathrm{~km}$ grid increments and 31 vertical layers centered over the active part of Augustine Volcano (Fig. 2). Augustine Island extends about $8 \mathrm{~km}$ by 11 $\mathrm{km}$ in the south-north and west-east directions. In the model, Augustine Island encompasses several grid-cells. The active part of the volcano falls in one grid-cell. Thus, the volcanic emissions (Fig. 3) were treated as a point source analogous to the treatment of anthropogenic emissions from point sources in chemistry transport models (CTMs) [35]. In the cross-sections (Figs. 5-10), the volcanic source is located at 0 $\mathrm{km}$. Like for CTMs, this treatment does not capture nearsource processes. Since WRF, like other mesoscale models, uses the average terrain height within a grid-cell as the terrain height, Augustine Volcano is about half as high in the model as in nature. Thus, some effects will be evident at higher altitudes in nature than in the model. However, in the following analysis, differences among simulations with different volcanic scenarios are compared for simulations that all use the same model terrain. Thus, no differences in the model scenarios result from the lower elevation of the crater in the model than nature.

(a)
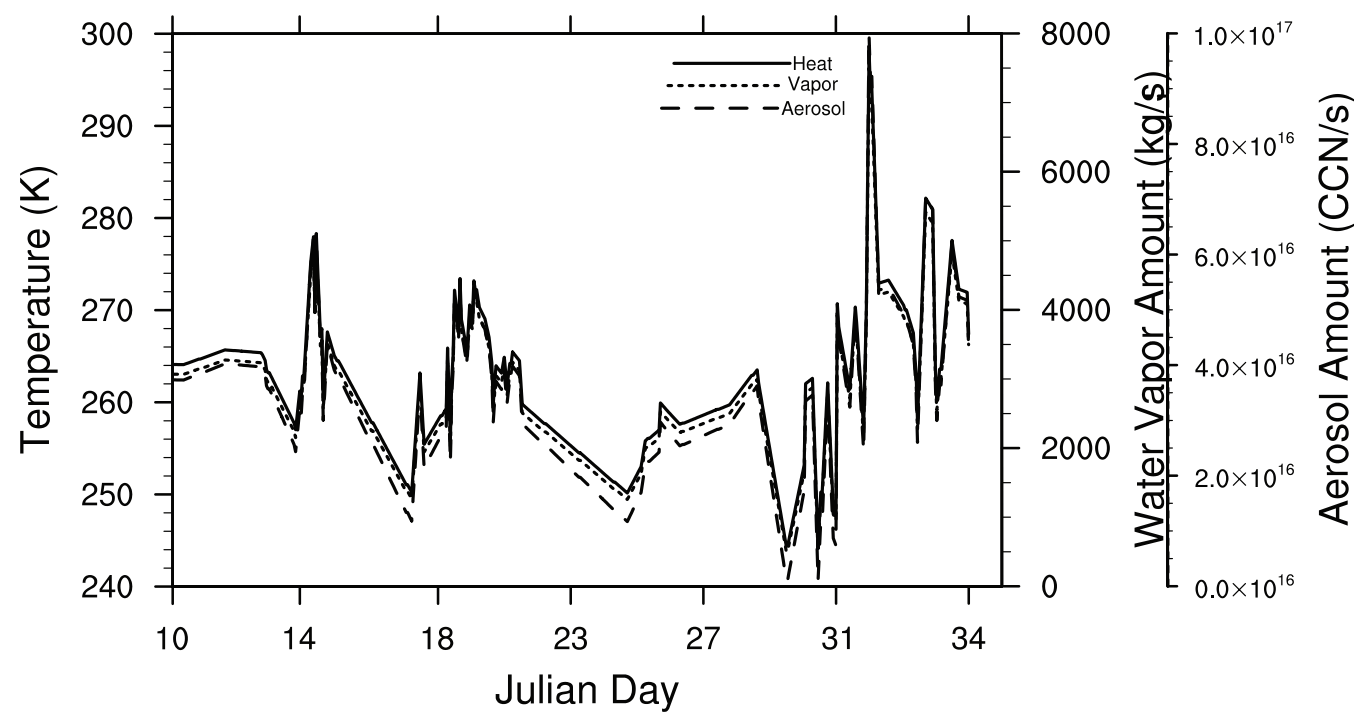

(b)

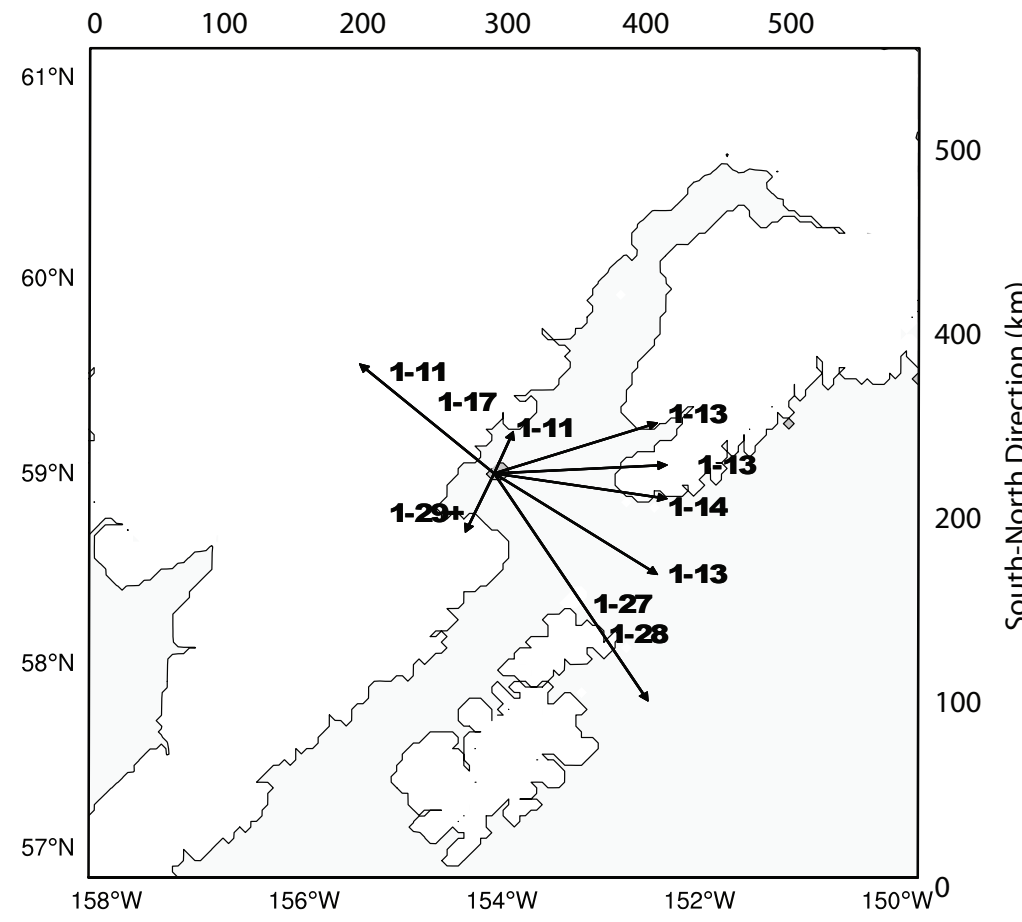

Fig. (3). Temporal evolution of (a) skin-surface temperature in the pixel encompassing Augustine Volcano as interpolated to the WRF gridcell encompassing the vent (see text for details), water-vapor release rate and aerosol-amount release rate and (b) ashfall sectors with respect to Augustine Volcano $\left(59.4^{\circ} \mathrm{N}, 153.4^{\circ} \mathrm{W}\right)$ as assumed in the scenarios described in the text. 

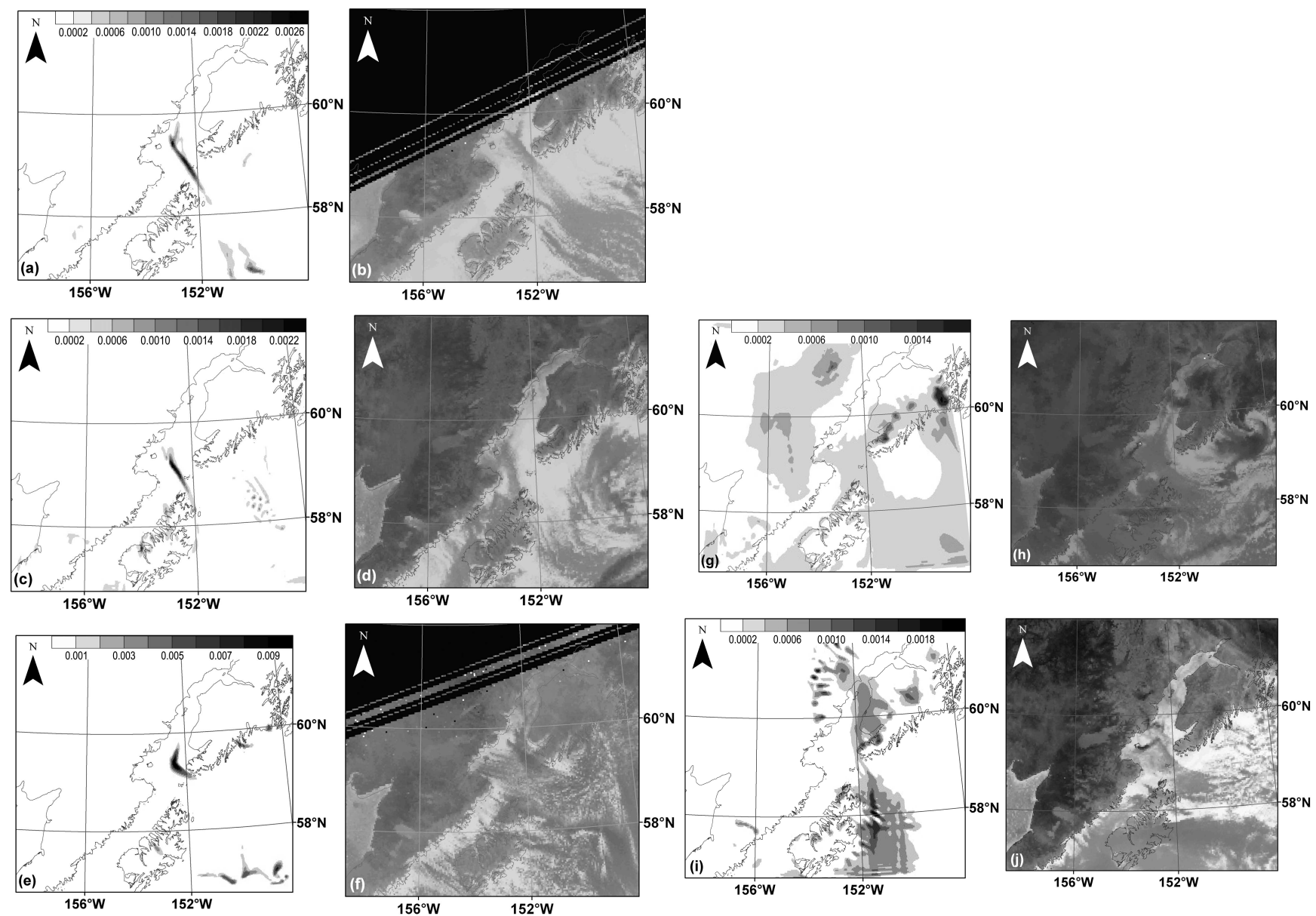

Fig. (4). Comparison of cloudiness obtained by the control simulations shown as sum of cloud and hydrometeor mixing ratios (g/kg) and NOAA-AVHRR channel 4 data as (a) simulated and (b) observed for January 25, 2006, 0131 UTC, (c) simulated and (d) observed for January 26, 2006, 0247 UTC, (e) simulated and (f) observed for January 28, 2006, 0157 UTC, (g) simulated and (h) observed for January 29, 2006, 1515 UTC, and (i) simulated and (j) observed for January 30, 2006, 1634 UTC, respectively. The black areas in parts (b) and (f) denote missing data. Note that comparisons of other simulation times and overpasses look similar (therefore not shown).

Cloud microphysics at the resolvable scale were considered by a modified version of Thompson et al.'s [36] six water class (water vapor, cloud-water, rainwater, cloud ice, snow, graupel), two-moment scheme. These modifications, made in accord with Mölders and Olson [30], serve to include volcanic aerosol effects. Herein cloud droplets and cloud-ice particles were initialized based on specific equations for $\mathrm{CCN} / \mathrm{IN}$ as functions of supersaturation and $\mathrm{CCN} / \mathrm{IN}$ concentrations. To avoid further degrees of freedom we applied a background aerosol profile over the entire model domain with a fixed radius dispersion spectrum, and assumed for simplicity that all aerosols can serve as $\mathrm{CCN} / \mathrm{IN}$ in all the 16 simulations. In all simulations that consider volcanic aerosol release, the assumed aerosol release (Fig. 3a) alters the aerosol profile and radius dispersion spectrum within the volcanic plume. Aerosol release was assumed to occur in the grid-column that includes the active volcanic part. All volcanic aerosols were assumed to act as CCN/IN. The Grell-Dévényi [37] cumulus scheme was applied to consider the effects of subgrid-scale convection. However, during this episode, cumulus convection was negligible.

Atmospheric boundary layer (ABL) processes were described using the Yonsei University scheme [38] that assumes non-local gradient fluxes. The Rapid Radiative Transfer Model (RRTM; [39]) and Dudhia scheme [40] were used for treating long-wave and shortwave radiation, respectively. The RRTM considers multiple bands, trace gases, aerosols and microphysical species in determining long-wave radiation fluxes. The short-wave radiation scheme considers cloud optical depth, cloud albedo, clear-sky absorption and scattering by cloud particles and aerosols.

The exchange of water vapor and heat at the surfaceatmosphere interface was determined by the Rapid Update Cycle land-surface model LSM; [41, 42]. This LSM consists of a one-layer canopy model, a multiple layer snow model, and a six layer soil model considering frozen soil physics. Snow-albedo is diagnosed as a function of snow depth and time since last snowfall. Each new snow event refreshes snow-albedo values. During the episode of interest, a closed snow cover existed on land. We assumed that forests have intercepted snow and all canopies are snow-covered. In all simulations assuming ashfall, snow-surface albedo was decreased by $10 \%$ of its absolute initial value where a volcanic scenario assumes ashfall occurrence (Fig. 3b). The main advantage of initializing the ashfall distribution rather than considering it explicitly is the reduction of degrees of freedom. In simulations considering volcanic heat release, 
(a)

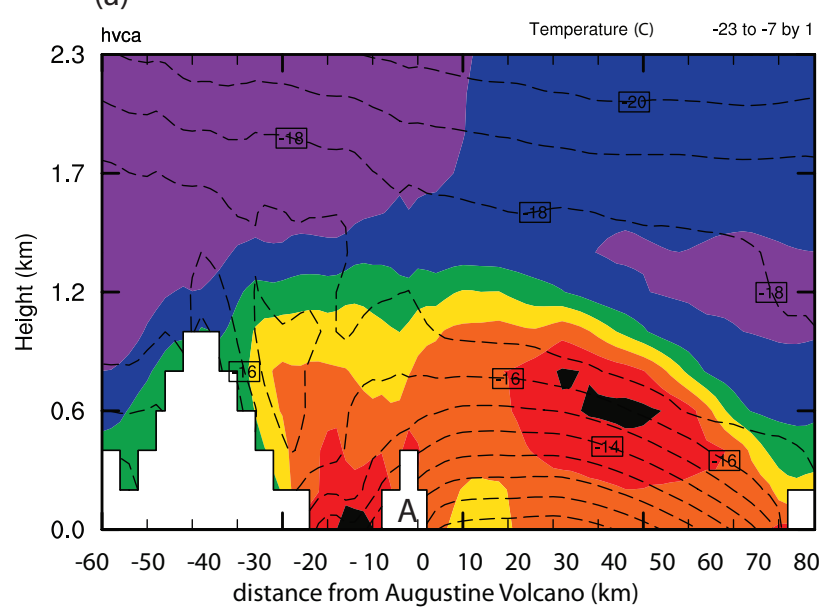

Relative Humidity (\%)

(c)

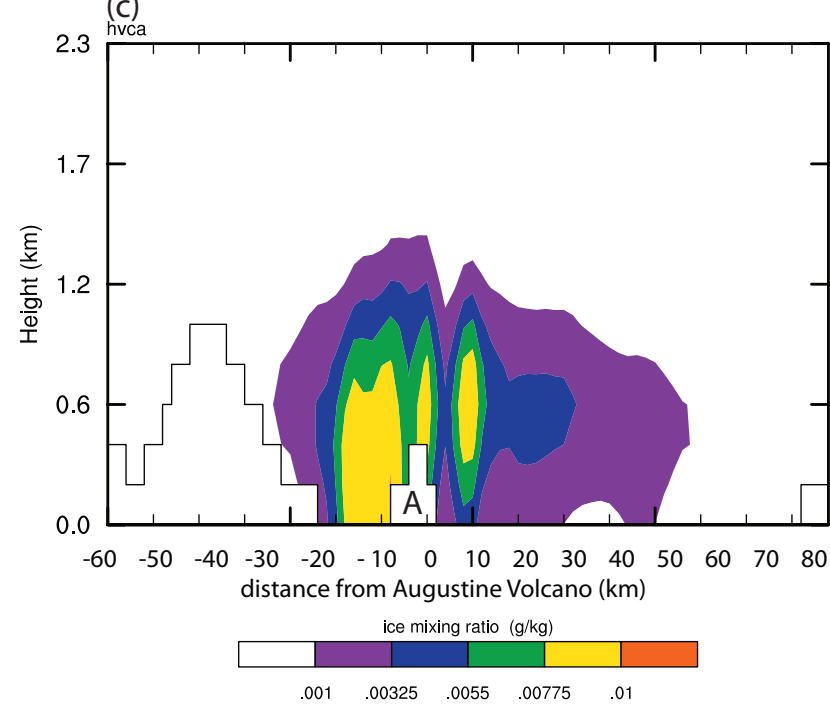

(b)

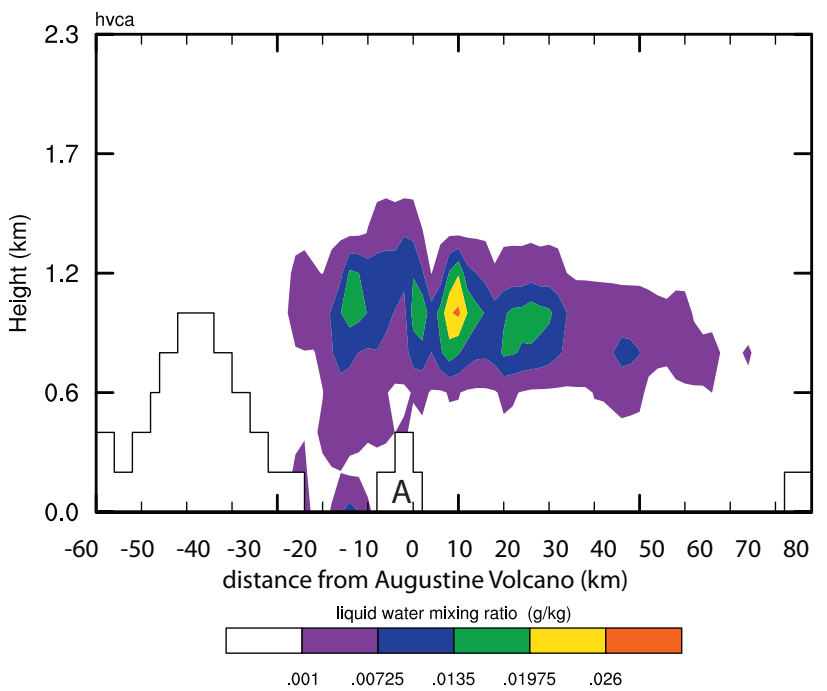

(d)

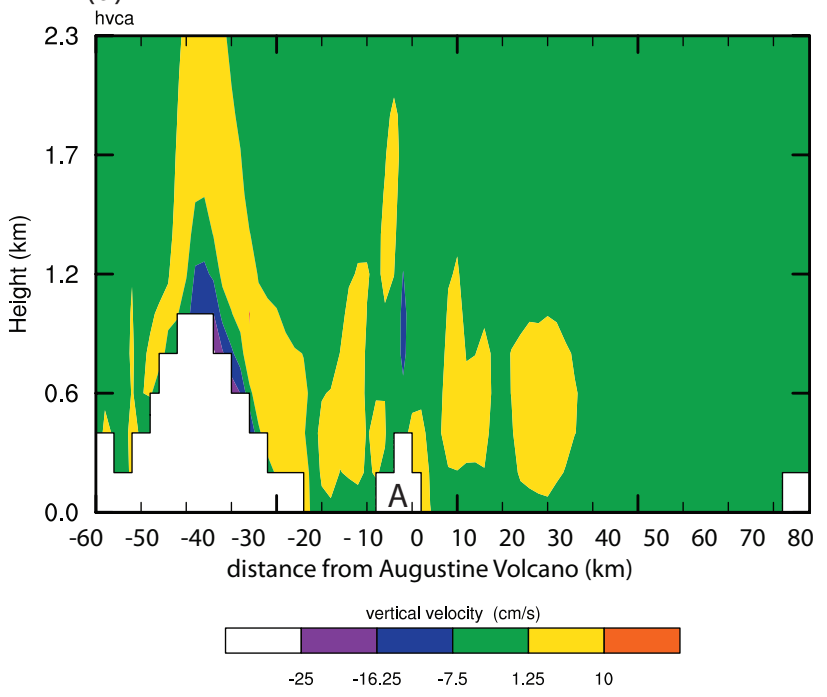

Fig. (5). Cross section through the atmospheric boundary layer for daily averages of (a) relative humidity (color filled contours) and temperature (dashed lines), (b) liquid (cloud water and rainwater) mixing ratio, (c) ice mixing ratio, and (d) vertical velocity for January 25 , 2006. Augustine Island is indicated by the letter A.

Advanced Very High Resolution Radiometer (AVHRR)derived brightness temperature values for the pixel holding the active part of Augustine Volcano served as skin-surface temperature in the heat balance equation of the LSM for the grid-cell that represents the active part of the volcano. An adjustment for the difference in grid-cell size $(4 \mathrm{~km} \times 4 \mathrm{~km})$ and the pixel size that varies depending on the location of the volcano within the satellite passage, was made. This parameterization represents radiative heat from the hot caldera and the related heating of surface air, but not hot air released directly from the volcano. Note that atmospheric heating from the eruption may be much higher when directly released hot air is included. However, since no data on directly released hot air were available from Augustine Volcano or similar Aleutian volcanoes, we restricted our scenario to radiative heat (denoted volcanic heat release hereafter).
Meteorological variables, snow cover and height, sea-ice distribution, land surface and sea surface temperatures (SST), and soil moisture and temperature states were initialized using the $1^{\circ} \times 1^{\circ}$, six-hour, global final analysis National Center for Atmospheric Research and National Centers for Environmental Protection reanalysis data. These data also served as boundary conditions through each simulation. The WRF pre-processor interpolated these data onto the model domain depending on topography and landwater distribution for details see [34]. Note that to reduce the degrees of freedom SST were hold constant throughout each $24 \mathrm{~h}$ simulation, while land-surface temperatures were determined each time step.

We ran 24-hour simulations for each day for January 10 , 2006, 0000 UTC through February 2, 2006, 0000 UTC. Note that Mölders [43] showed that ensemble means do not necessarily provide better results than a $24 \mathrm{~h}$ forecast. For 
(a)
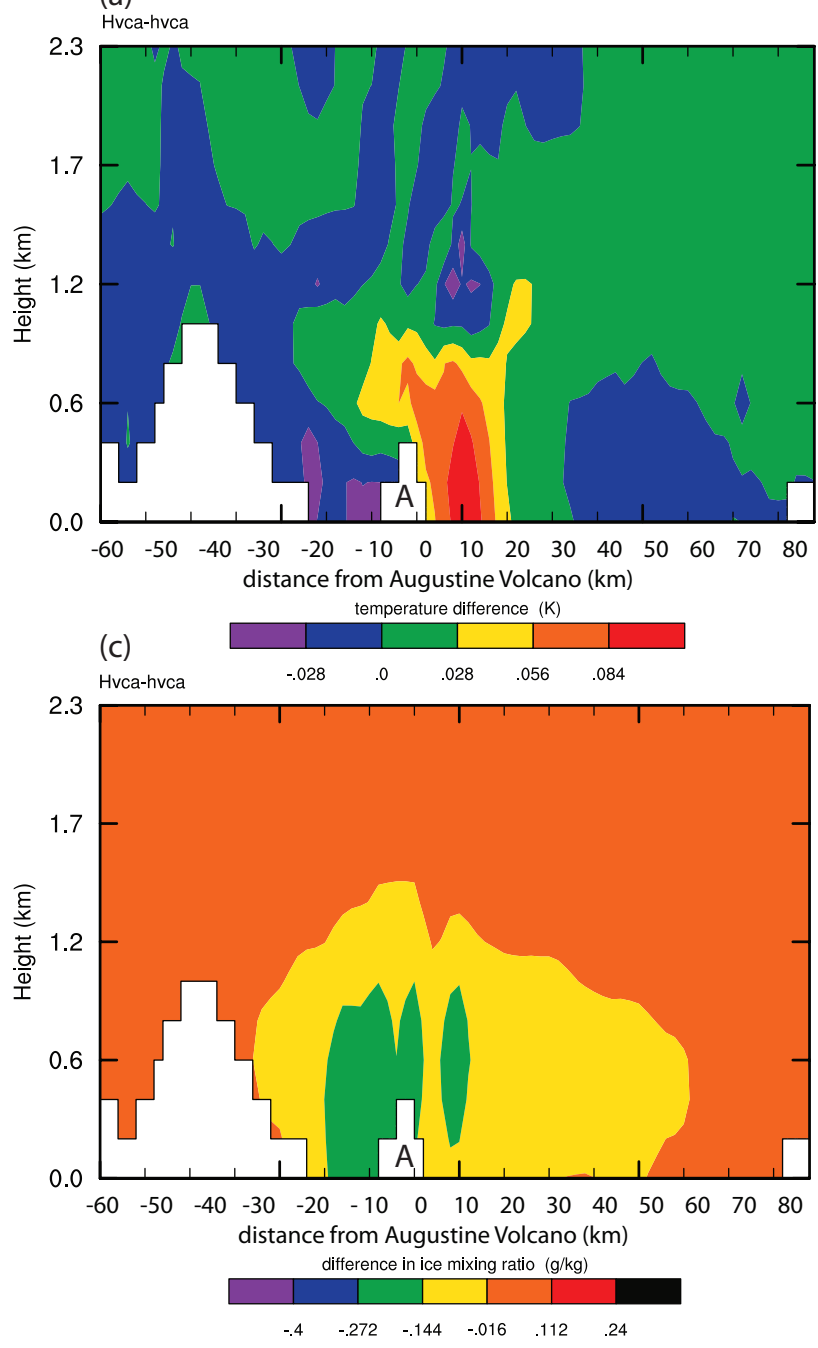

(b)
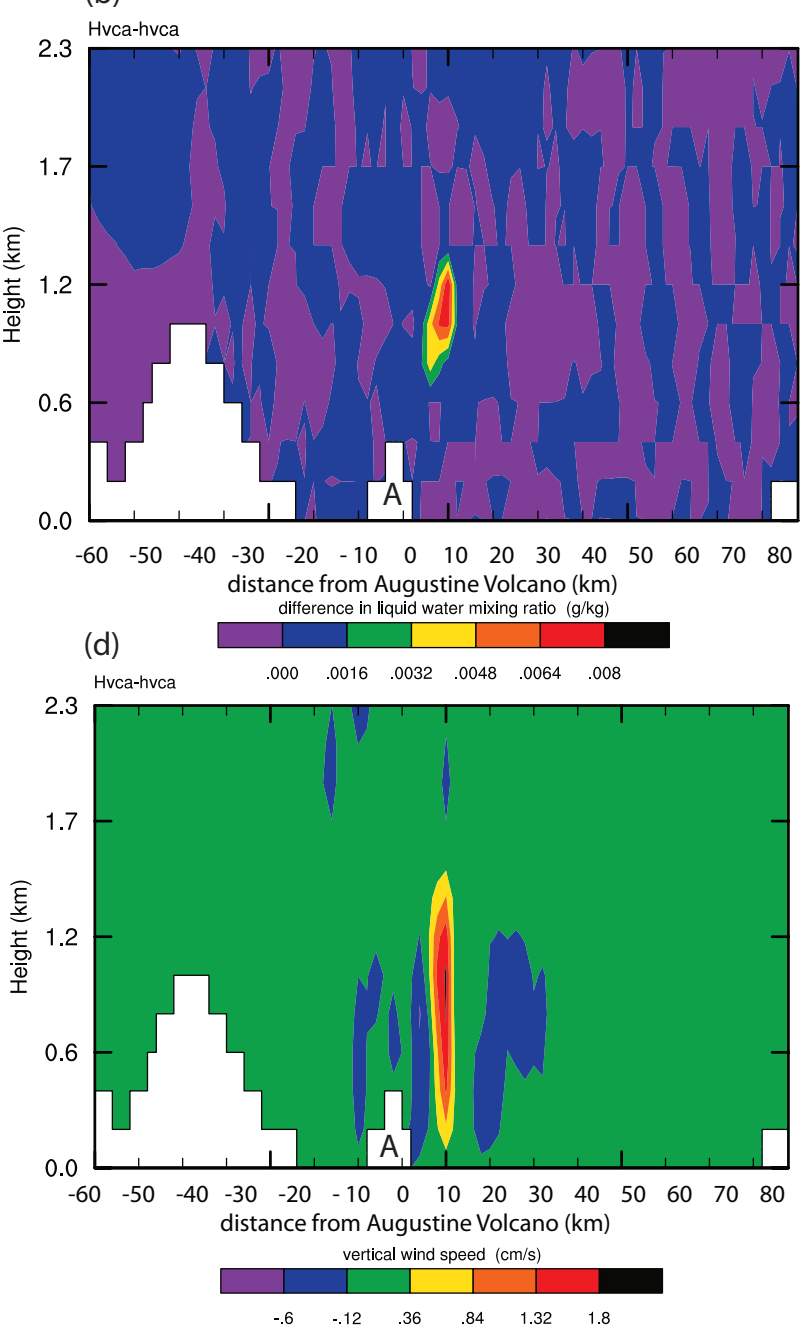

Fig. (6). Cross section through the atmospheric boundary layer for daily differences between the simulation with volcanic heat release (Hvca) and the control simulation (hvca) of (a) temperature, (b) liquid (cloud water and rainwater) mixing ratio, (c) ice mixing ratio, and (d) vertical velocity for January 25, 2006. Augustine Island is indicated by the letter A. The release is assumed to be in the grid-column that represents the vent (at $0 \mathrm{~km}$ ), and not in all grid-cells covering the island. Since wind direction changes during the day or varies, differences in quantities may occur on both sides of the island even if a wind direction dominates. The scale is spread between the minimum and maximum difference occurring for the comparison of these two simulations, i.e. gives the maximum differences for this respective day. Note that this example shows average responses (not the strongest, not the weakest) found in response to a relatively weak forcing.

each day, 16 simulations assuming different volcanic scenarios were performed. All $16 \mathrm{WRF}$ simulations started from the same initial conditions and used the same boundary conditions. Thus, differences among simulations for the same day reflect the operation of the volcanic effects over the 24 hours of each day. This model setup was chosen to examine the short-term impacts and to be able to compare the impacts of volcanic effects for different synoptic situations without inclusion of medium-term impacts (e.g., transport back into the region). We were interested in the short-term impacts as Lagranian models to assess ash-plume propagation to provide warnings for air traffic, are typically driven by the latest available $24 \mathrm{~h}$ operational NWP [25]. Consideration of medium-term effects would require nesting within a global model.

\subsection{Scenarios}

The volcanic perturbations, release of heat, water vapor, and aerosols and consequent ashfall are referred to as factors hereafter. An important aspect for our theoretical investigation was to separate variance in an atmospheric quantity (e.g., precipitation) ascribable to one volcanic factor from that ascribable to other volcanic factors. Thus, we restricted our investigations to four simple, artificial scenarios plus all possible combinations of the four factors for 16 simulations per day: one control simulation (no volcanic factors, simulation hvca), four simulations each with different individual factor enabled (Hvca, $\mathrm{hVca}, \mathrm{hvCa}$, hvcA), and 11 simulations for all possible combinations of factors. Here the letters $\mathrm{H}, \mathrm{V}, \mathrm{C}$, and A stand for the release 
(a)

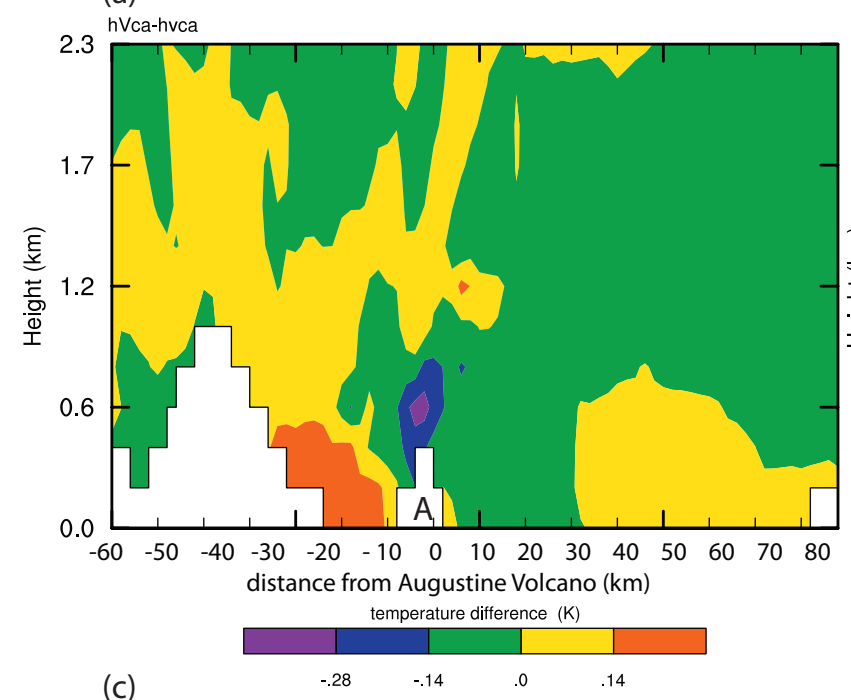

(c)

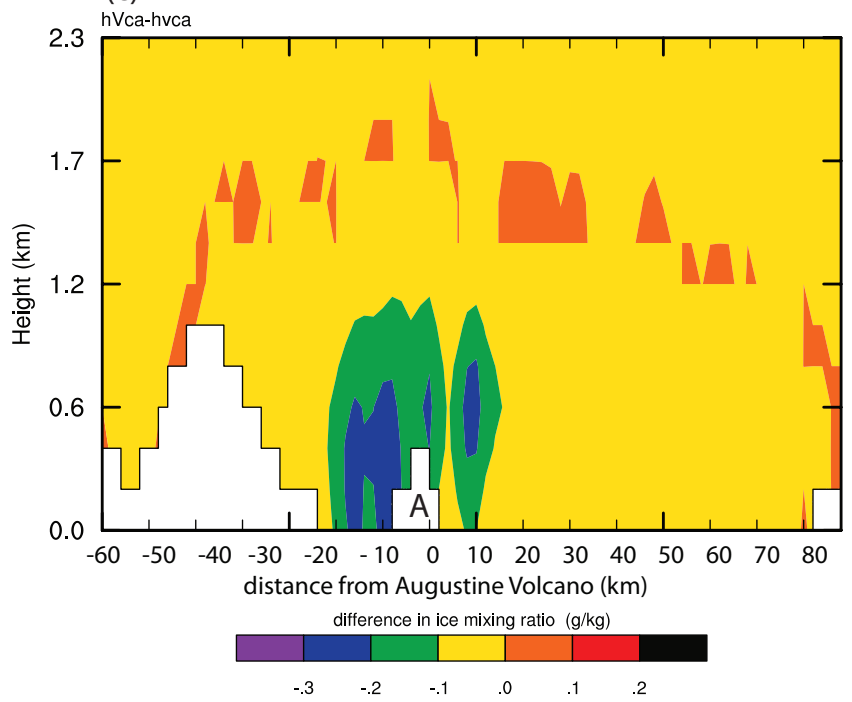

(b)

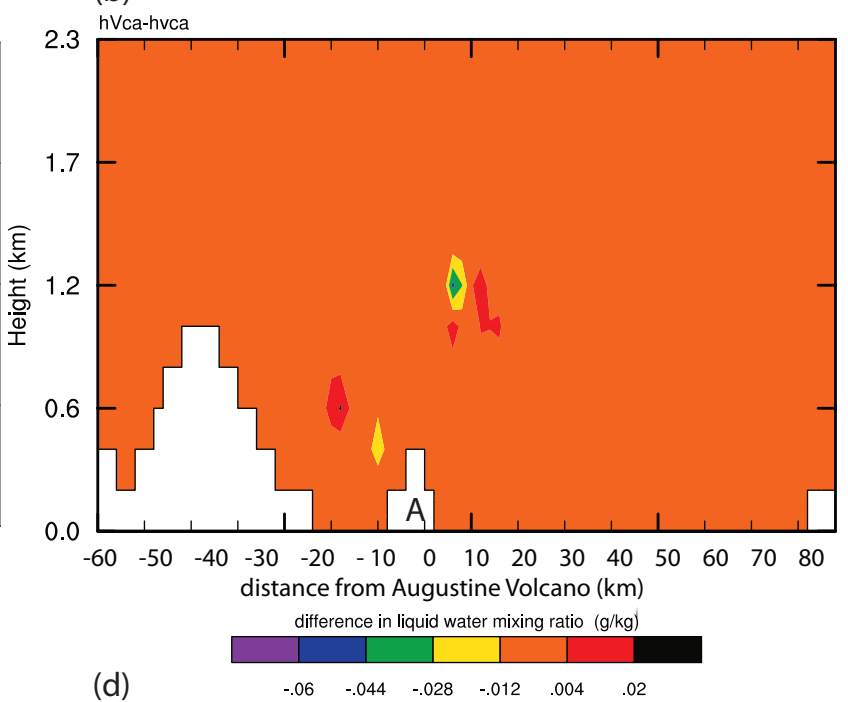

d)

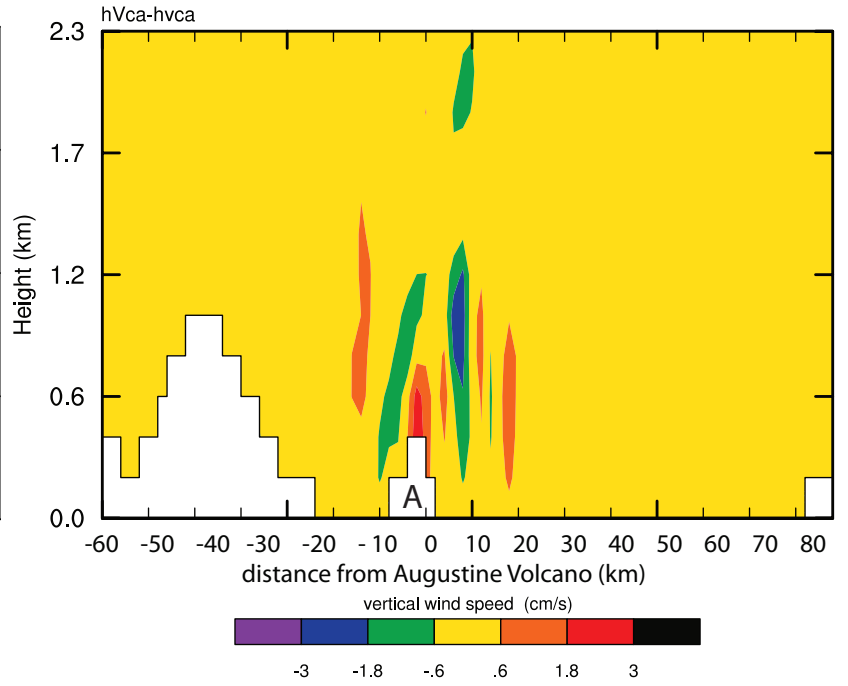

Fig. (7). Like Fig. (6), but for daily differences between the simulation with water vapor release alone (hVca) and the control simulation (hvca). Note that scales differ among figures for better visualization of individual differences occurring in response to a forcing. The scale is spread between the minimum and maximum difference occurring for the comparison of these two simulations.

of $\boldsymbol{h}$ eat, water vapor, and aerosols, which are assumed to act as $\boldsymbol{C C N}$ or IN, and $a$ shfall, respectively. Capital letters represent the factor switched on; small letters denote the factors switched off. In the following, this nomenclature addresses the simulations and their results.

In nature, all four volcanic factors have very complex temporal behaviors. Real eruptions often only last for minutes; fluxes of heat and matter rise rapidly and fall off exponentially after the burst [44]. In the case of the 2006 Augustine Volcano eruption, the volcano did not continuously put ash into the atmosphere and lava was often the primary source of strong heat release with little water vapor involved. An exception was January 28 to 30, 2006 when nearly continuous emission occurred. Also in Augustine Volcano's explosions, much of the thermal energy was used up in heat of fusion of volcanic particles, vaporization of water, and mechanical energy. From January
11 to February 2, 2006, lava was actually the primary source of heat from Augustine Volcano's eruption [32].

Such non-correlated behaviors make interpretation of the factors' impacts on cloud and precipitation formation, the impact of interaction between factors, and the combined impact of factors quite difficult or even impossible. Therefore, to be able to examine interaction (enhancing or diminishing) among the impacts of various factors we assumed a simplified, artificial scenario where factors were in a given prescribed relationship to each other (Fig. 3a). For simplicity, we tied the scenarios for release of water vapor and aerosols to that of radiative heat. This means these artificial scenarios do not replicate the actual situation during the 2006 eruption and represent assumed artificial scenarios.

Brightness temperatures estimated from the AVHRR data for the pixel holding Augustine Volcano were used to develop a heat-release scenario. Depending on the location within a satellite passage, the pixel size can vary largely. 
(a)
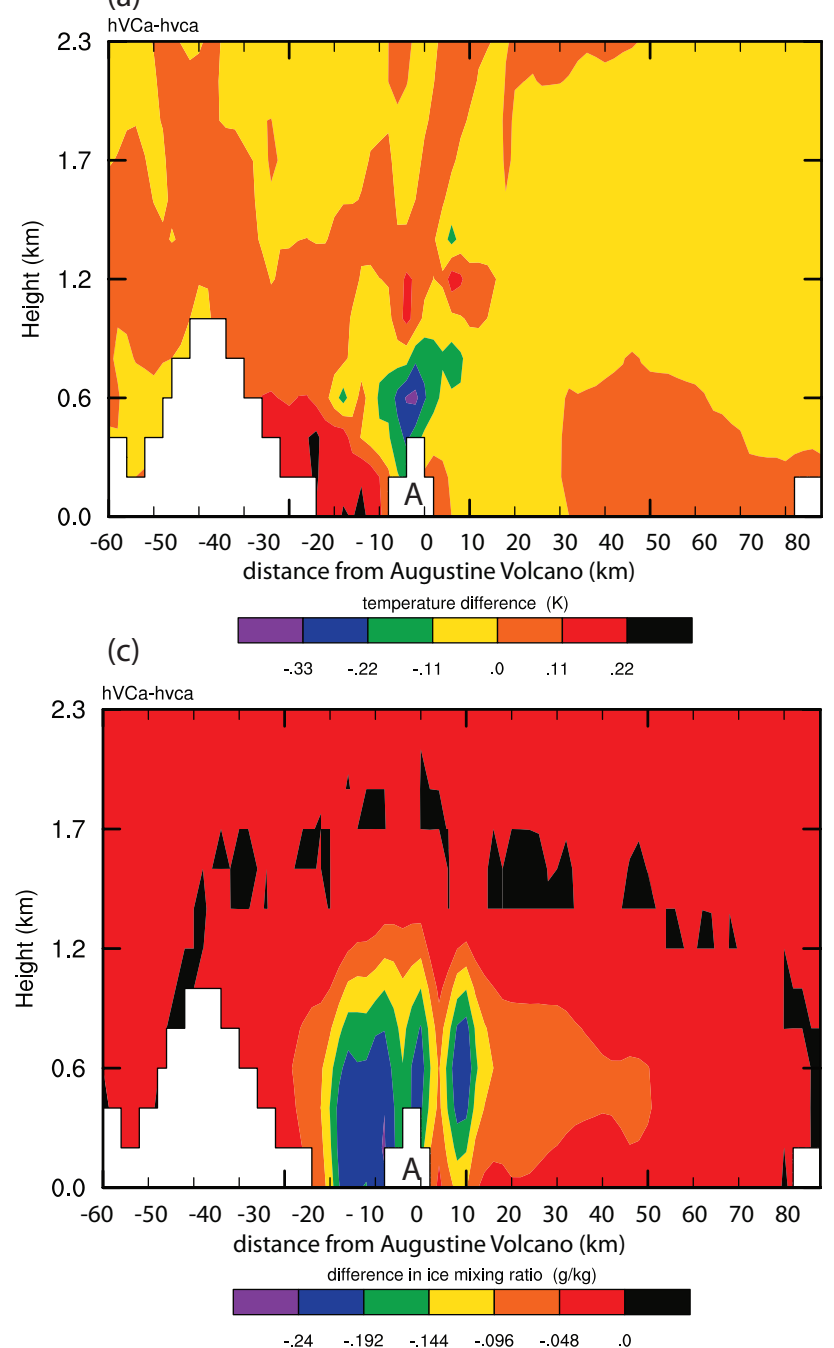

(b)
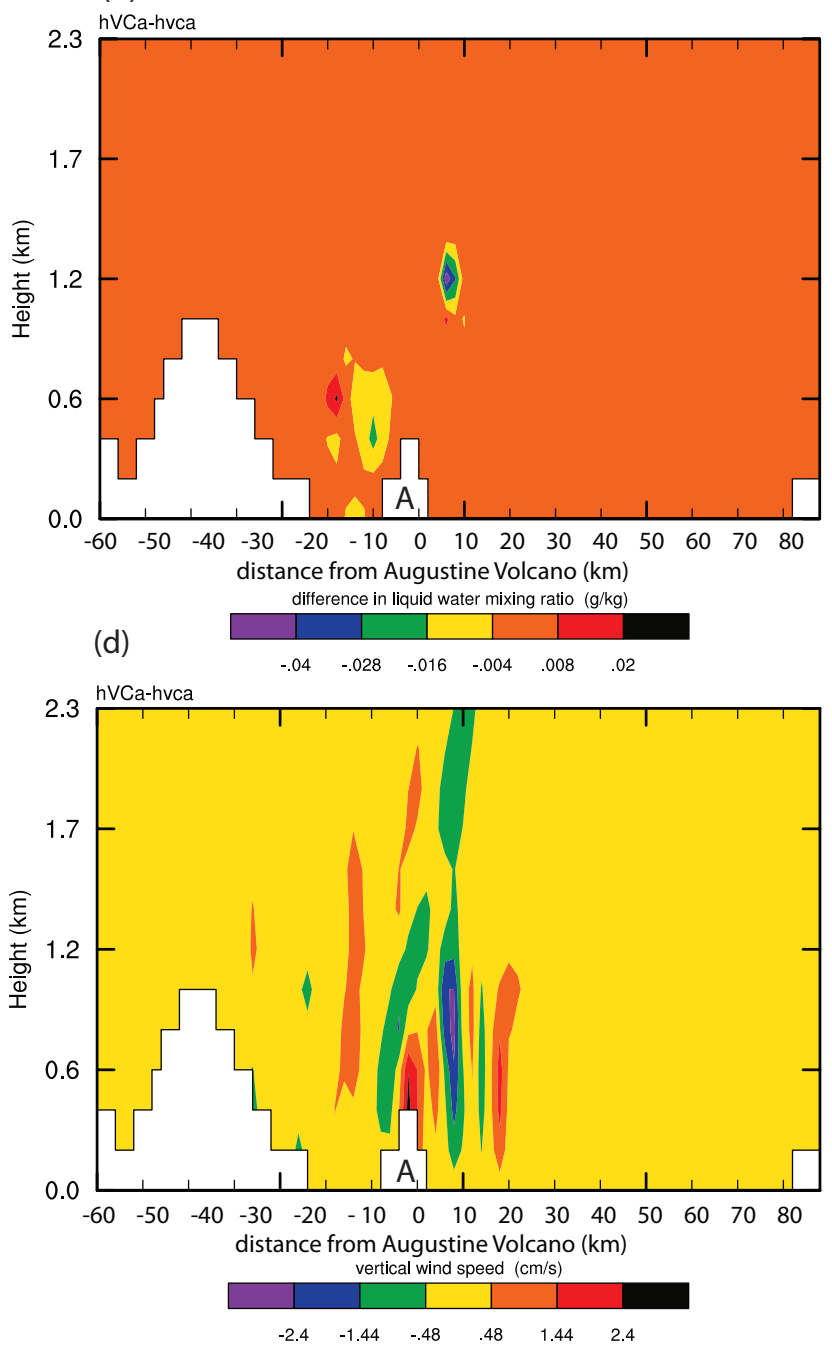

Fig. (8). Like Fig. (6), but for daily differences between the simulation with concurrent water vapor and aerosol release (hVCa) and the control simulation (hvca).

However, only the vent is the "hot spot". Thus, the brightness temperatures of the pixel holding the vent of Augustine Volcano were weighted by their pixel size and the size of the vent, and interpolated to the size of the grid-cell. Since WRF does not consider any subgrid-scale heterogeneity, the radiative heat from the caldera was distributed equally over the grid-cell weighting the grid-cell size with that of the vent. To obtain a continuous scenario of heat release from the temporally irregular satellite measurements, brightness temperature data were interpolated linearly between each satellite pass (Fig. 3a). Note that this procedure yields lower heat release than in the actual event, may miss peaks that may have occurred in between satellite passages, and hence may underestimate the actual heat released.

As in chemistry transport modeling e.g. [35], plume raise was accounted for and volcanic emissions were assumed to be immediately homogeneously distributed within the gridcells into which they are emitted. The neglecting of small- scale processes related to mixing and segregation effects occurring along the plume means a local underestimation of buoyancy $[45,46]$. This neglecting also excludes heterogeneity of emissions that might occur within the grid-cell and might influence processes within that particular grid-cell $[45,46]$. However, on average, the impact of small-scale processes on the atmospheric variables represented by a gridcell can be considered as small for the artificial scenarios assumed here, because of the much larger volume-average of each grid-cell $(4 \mathrm{~km} \times 4 \mathrm{~km} \times$ layer thickness) compared to the volume of the plume within a grid-cell.

In nature, moisture release generally depends more heavily on the eruption type than on the eruption size [47]. The 1976, 1986 and 2006 eruptions of Augustine Volcano had similar eruption patterns (for details on the 1986 eruption see [48] or [49]). Since water vapor measurements were carried out for the 1976 eruption $[47,50]$, the range of these values $\left(10^{2} \mathrm{~kg} / \mathrm{s}\right.$ to $\left.10^{5} \mathrm{~kg} / \mathrm{s}\right)$ was adopted for a simple water vapor emission scenario. For simplicity of the 
(a)
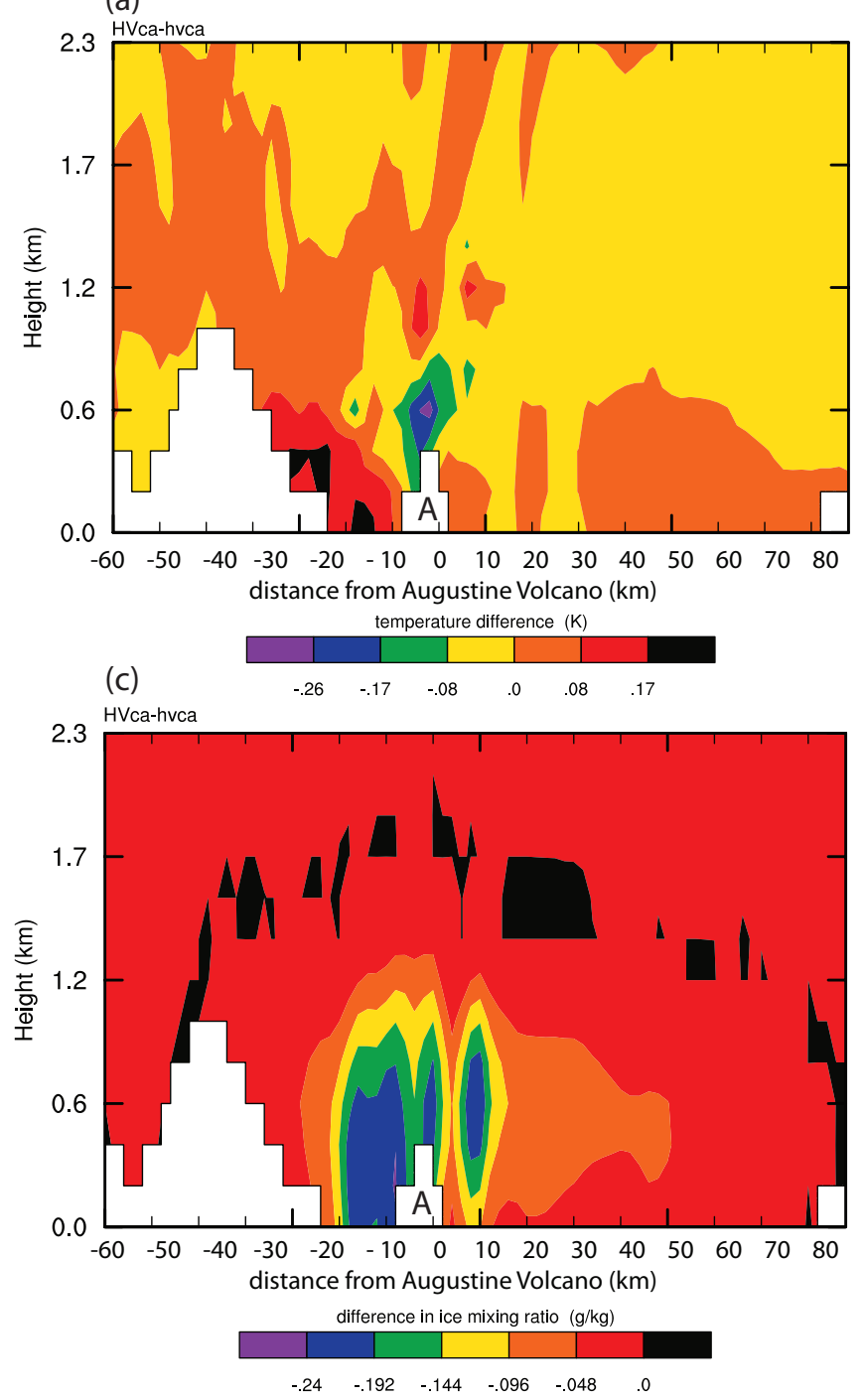

(b)
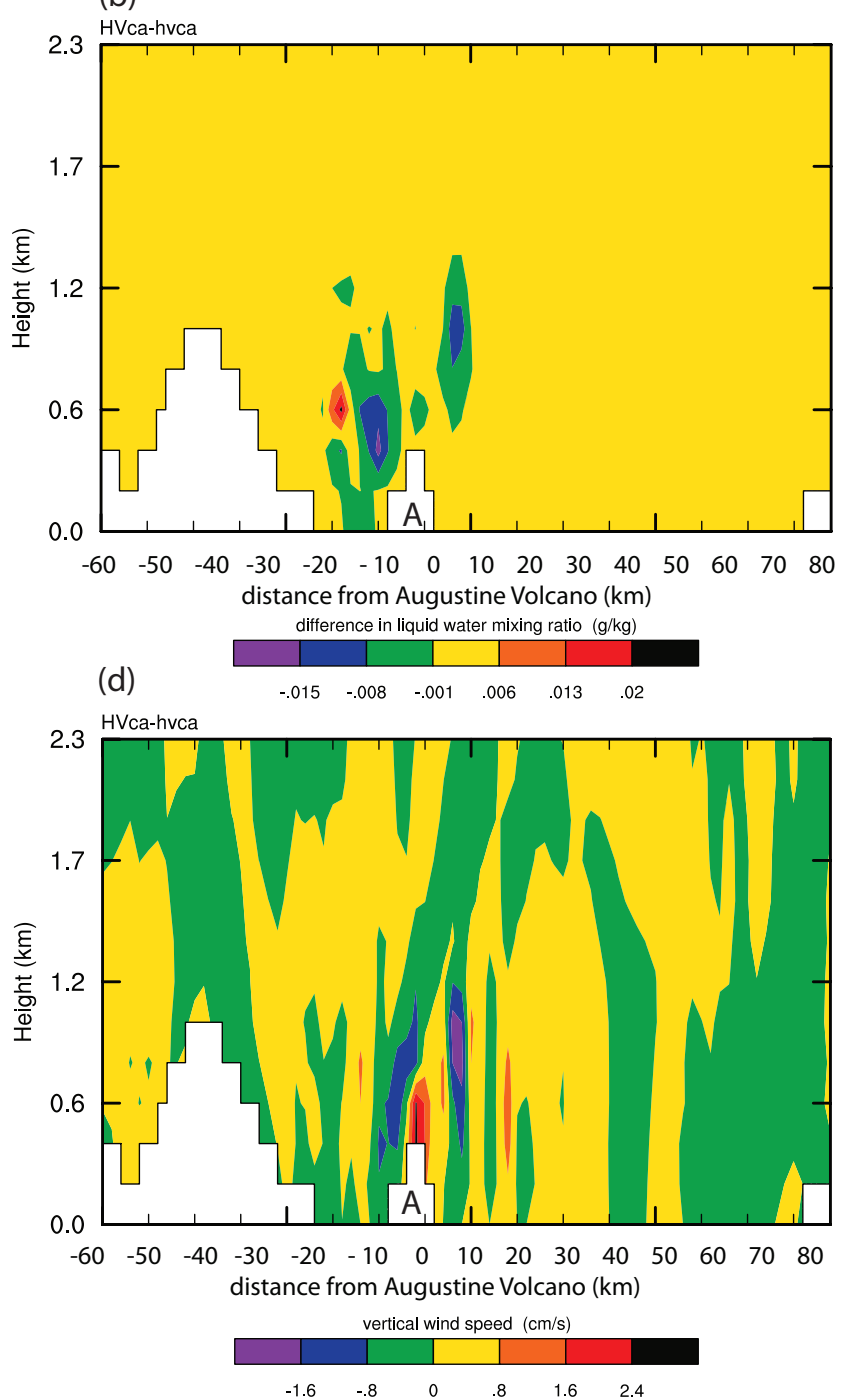

Fig. (9). Like Fig. (6), but for daily differences between the simulation with concurrent heat and water vapor release (HVca) and the control simulation (hvca).

experimental design, the water-vapor values were correlated with the skin-temperatures assumed in the heat-release scenario (Fig. 3a).

The release of aerosols was estimated using aerosol particle fluxes measured during previous Alaska volcanic eruptions $[51,52]$. This range of $10^{15}$ to $10^{17}$ particle/s was correlated with the heat-release scenario, such that, as skin temperature increases, the number of aerosols released increases (Fig. 3a).

The implementation of albedo decrease in response to ashfall relied on daily vector maps of ashfall projection obtained from Wallace [53]. Ashfall was assumed in a $45^{\circ}$ dispersion angle downwind from the Augustine Volcano grid-cell centered on the corresponding vector for each day (Fig. 3b). Note that in our study, ashfall only influences albedo on land or sea-ice and that during the Augustine Volcano eruption daylight hours were relatively short, i.e. the potential impact of changed albedo on the radiation budget and temperature (via temperature-albedo feedback) may be small. We included ashfall to assess at least its potential impact and feedbacks on local weather because large regions of Alaska are snow-covered for more than seven months each year and ashfall impacts may interact with the impacts of the volcanic emissions.

\subsection{Synoptic Situation}

On January 10, 2006, a weakening low-pressure system existed over the Gulf of Alaska (see Fig. 2 for locations). It gradually was replaced by a weak high-pressure system by January 13. Temperatures ranged between $-12^{\circ} \mathrm{C}$ and $4^{\circ} \mathrm{C}$, which is about $8^{\circ} \mathrm{C}$ above the climate average. A weak lowpressure system caused a further pressure decrease on January 17 , with snowfall through January 18 . On January 21, a strong low-pressure system developed over the Aleutian Islands, causing a notable pressure decrease in the area over the next two days. This low-presure system brought $2 \mathrm{~m}$ air temperatures back to seasonably normal values between $-23^{\circ} \mathrm{C}$ and $-6^{\circ} \mathrm{C}$ in the area of interest. As the center of the low-pressure system moved northward, heavy 
(a)

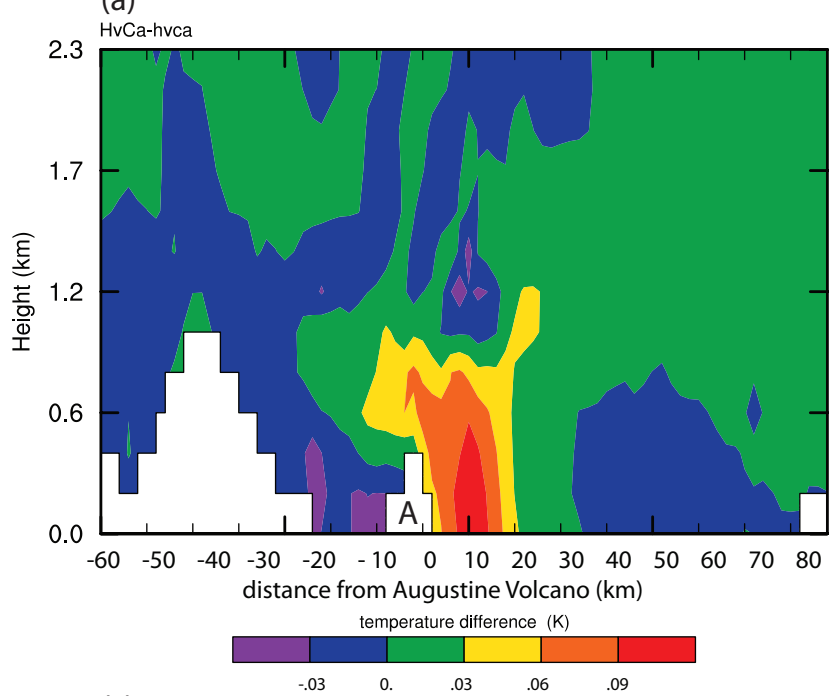

(c)

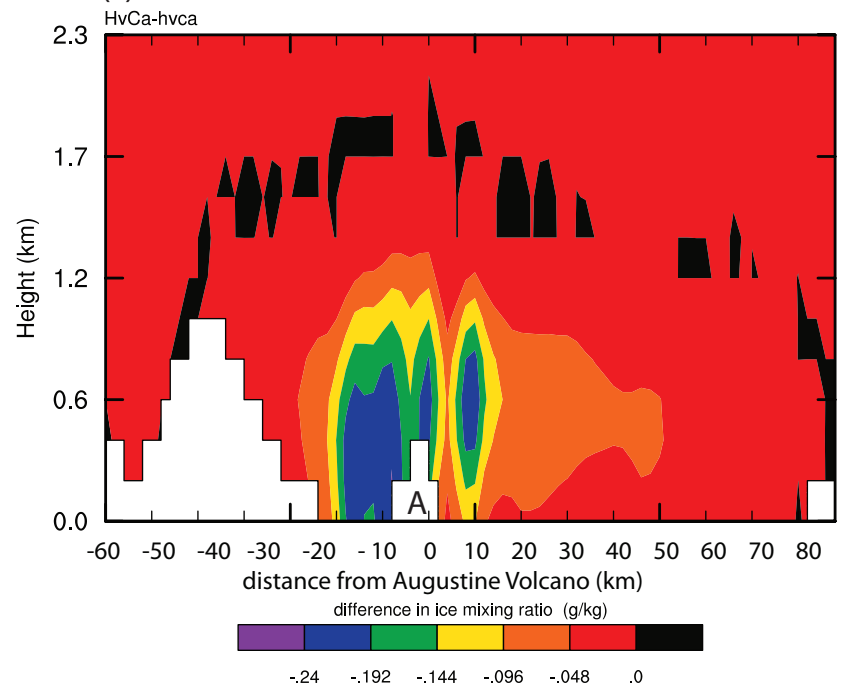

(b)

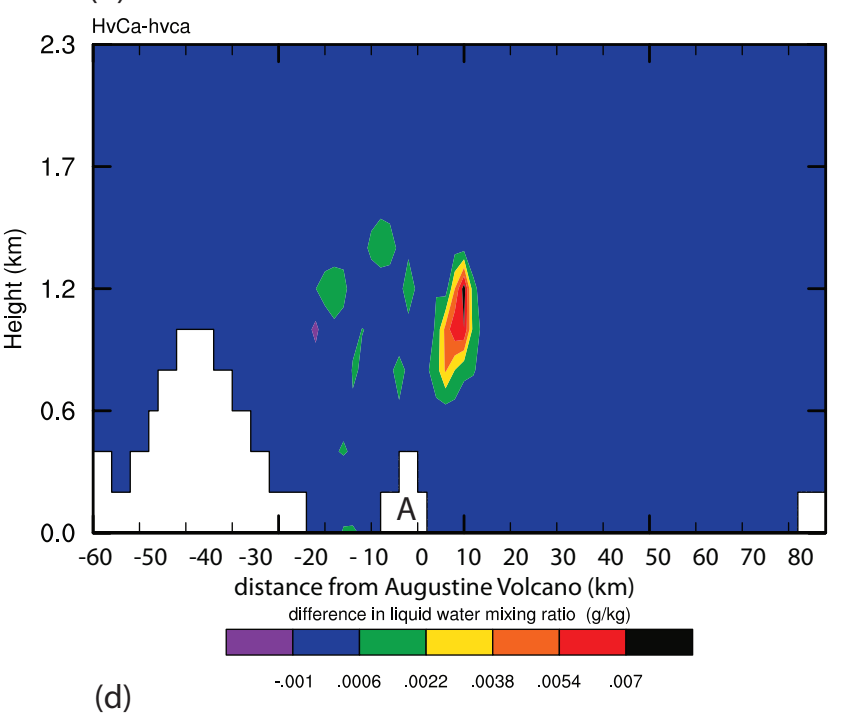

(d)

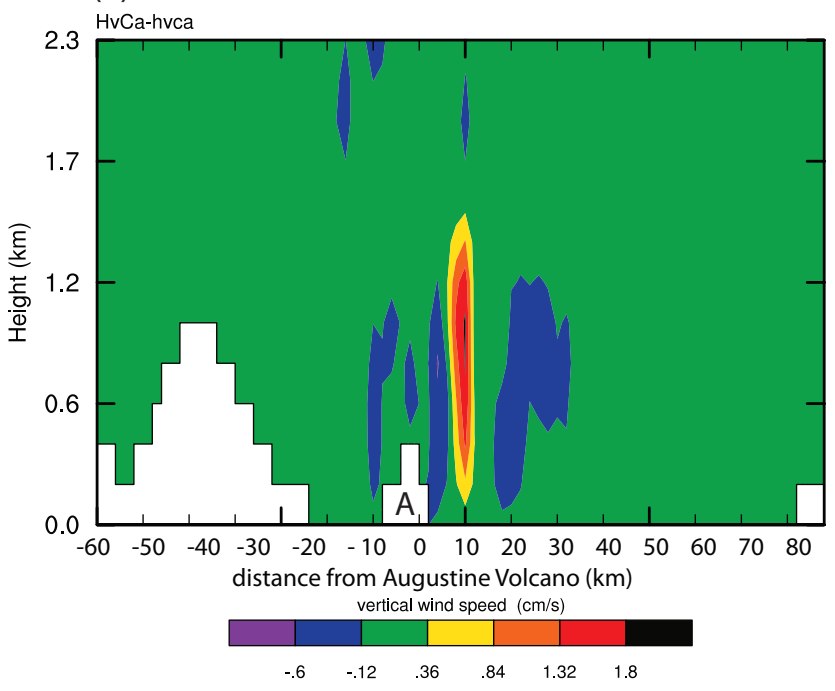

Fig. (10). Like Fig. (6), but for daily differences between the simulation with concurrent heat and aerosol release (HvCa) and the control simulation (hvca).

snowfall (up to $20 \mathrm{~mm} / \mathrm{d}$ water equivalent) and locally mixed with rain occasionally occurred over the region. On January 24 , sea-level pressure increased slightly, but by January 25 a weak low-pressure system moved into the region from the south, providing snowfall again locally, occasionally mixed with rain for the remainder of the period.

\subsection{Observations}

For confidence in the model performance, all WRF simulations were compared with analysis data $\left(1^{\circ} \times 1^{\circ}\right.$ resolution), data from 47 sites within the region (Fig. 2) and satellite data. Surface observational data stem from the National Climatic Data Center and Western Region Climate Center; the satellite images were acquired by the Geographic Information Network of Alaska (GINA) facility at the University of Alaska Fairbanks. Atmospheric variables evaluated include daily-accumulated precipitation, maximum temperature, and minimum temperature from 25 sites and hourly cloud cover, wind speed, pressure, temperature, dew- point temperature, and precipitation from 22 additional sites (Fig. 2). We calculated daily means from the hourly data. For consistency with the daily averages reported for some quantities, calculated daily averages encompass 24 hours from 1500 UTC (0000 Alaska Standard Time (AST)) to the same time the next day. The evaluation using daily data includes data from 47 sites; the evaluation using hourly data includes data from 22 sites.

Quantitative and categorical skill-scores e.g., [54-56] were calculated for the entire episode using data from all sites. Quantitative skill-scores evaluate how close a simulated quantity is to the observed value at a site. Categorical skill-scores assess the simulations under consideration of events, i.e. how frequently an event occurred compared to the number of times the event is simulated. Typically, a threshold value of $0.25 \mathrm{~mm}$ per time (either per hour or day, depending on the observation dataset) serves for evaluating categorical precipitation forecasts e.g., [57]. This threshold value roughly coincides 
with the average precipitation per event for the Cook Inlet region in January [58]. Thus, a threshold value of 0.25 $\mathrm{mm} / \mathrm{h}$ was used for determining the hourly categorical scores.

Since WRF does not determine cloud fraction, "cloud existence" was evaluated instead in accord with Anthes et al. [55]. We determined this quantity as follows: if WRF simulates a cloud or ice mixing ratio greater than $0.001 \mathrm{~g} / \mathrm{kg}$ for any grid-cell in a vertical grid-column, clouds will be assumed to exist within that grid-column. Correspondingly, clouds existed when any cloud fraction greater than zero was reported.

Simulated cloud patterns were compared with images acquired by the AVHRR to further examine whether WRF captures the general cloud distribution. These AVHRR data were available from sensors onboard NOAA-12, one of the satellites in the NOAA Polar Orbiter series. NOAA-12 orbits the Earth at a distance of $\approx 833 \mathrm{~km}$, with a repeat coverage over the same spot approximately every 102 minutes. The AVHRR sensors record data at a spatial resolution of $\approx 1.1$ $\mathrm{km}$ in the nadir look direction in five spectral channels: channe1 1 (red: $0.58-0.68 \mu \mathrm{m}$ ), channel 2 (near-infrared: $0.725-1.10 \mu \mathrm{m}$ ), channel 3 (middle infrared: $3.55-3.93 \mu \mathrm{m}$ ), channel 4 (thermal infrared: $10.30-11.30 \mu \mathrm{m}$ ), and channel 5 (thermal infrared: $11.50-12.50 \mu \mathrm{m}$ ). We used channel 4 thermal infrared images as this channel records primarily energy emitted from the targets (clouds, snow-cover, ocean, volcano, etc.) at this time a year. Note that average daylight is about $5.8 \mathrm{~h}$ per day.

\subsection{Analysis}

The main goals of our investigations were to assess theoretically (1) the impact of high-latitude moderate volcanic eruptions on clouds and precipitation and (2) how the effects of releases of heat, aerosols and water vapor, as well as reduced albedo, interact with each other. To achieve these goals the variance induced by the different factors and by the interaction between these factors has to be separated and quantified for objective comparison of the factors' impacts. ANalysis Of VAriance (ANOVA; $[56,58]$ is a technique that permits such separation and quantification. Many recent climate and meteorological studies have already applied successfully this technique to analyze factor interaction e.g., [30, 59-65].

In ANOVA theory, factors are referred to as treatments. We used a $2^{4}$-factorial ANOVA design [58] that assumes: fixed factors, a randomized design, and that each treatment satisfies the assumption of normality. The exponent represents the number of factors considered (ashfall, release of heat, water vapor, and aerosols) and the base number represents the level (either off or on). The appendix presents details on the mathematical framework.

The ANOVA design begins with a null hypothesis, where significance is tested using an f-test. ANOVA generates fvalues for all treatments, which are compared to expected test statistic values at the $95 \%$ confidence level. If ANOVA f-test values exceed the expected values, the null hypothesis will be rejected. In our investigation, the null hypothesis was that volcanic factors have no significant impact on clouds and precipitation. In the following, the word significant implies that changes or interactions are statistically significant as determined by the ANOVA or changes are statistically significant according to a Student t-test e.g., [56]. In the case of several factors switched on, the ANOVA evaluates whether effects of factors interact significantly and not whether the changes are significant. The latter was assessed by a separate Student t-test.

\section{RESULTS AND DISCUSSION}

\subsection{Evaluation of the Model Performance}

WRF's performance has been evaluated for a variety of cases (e.g., [66-70] including polar applications e.g., [43, 71, 72]. For polar regions WRF has a forecast skill equivalent to the well evaluated fifth-generation Pennsylvania State University-National Center for Atmospheric Research Mesoscale Model (MM5; [71, 73] or other modern mesoscale NWP models applied to mid-latitudes [43].

Comparison of the WRF simulations and analysis of air temperature, relative humidity, and wind shows no overall significant difference at the $95 \%$ confidence level for these fields at the standard pressure levels $(1000,850,700,500$, $300,200,100 \mathrm{hPa})$ and standard times (0000 UTC, 0600 UTC, 1200 UTC, 1800 UTC). This means that the reanalysis data are too coarse to identify the impact of the assumed volcanic effects. Note that cloud and precipitation particles, precipitation and vertical wind speed, which show the greatest significant differences among the 16 simulations (as discussed later), are not part of the analysis data.

Overall, WRF shows very good performance skills (Tables 1, 2) when compared with previous model evaluation studies of WRF and other modern NWP models (e.g., [67, 74-76]. The performance skill scores indicate that WRF, without inclusion of any volcanic effects (control simulation), well captures the temporal evolution and spatial pattern of observed state variables and cloud cover (e.g., Fig. 4). On average over the entire episode and all sites, WRF overestimates daily average $2 \mathrm{~m}$-temperature, dew-point temperature, $10 \mathrm{~m}$ wind speed, and precipitation by $0.9^{\circ} \mathrm{C}$, $2.8{ }^{\circ} \mathrm{C}, 1.1 \mathrm{~m} / \mathrm{s}$, and $1 \mathrm{~mm} / \mathrm{d}$, respectively; WRF generally underestimates daily mean sea-level pressure $(-1.1 \mathrm{hPa})$ and cloud existence for the episode considered here. Root mean square errors (RMSE) for daily average $2 \mathrm{~m}$-temperature, dew-point temperature, $10 \mathrm{~m}$ wind speed, pressure, and daily accumulated precipitation, cloud existence, daily maximum and minimum temperature are $5.5{ }^{\circ} \mathrm{C}, 6.5^{\circ} \mathrm{C}, 3.1 \mathrm{~m} / \mathrm{s}, 4.5$ $\mathrm{hPa}, 2.4 \mathrm{~mm} / \mathrm{d}, 0.8,4.0{ }^{\circ} \mathrm{C}$ and $5.5{ }^{\circ} \mathrm{C}$, respectively. The evaluation over the entire episode and all available sites with hourly data provides better skill-scores for $2 \mathrm{~m}$-temperature, dew-point temperature, wind speed, pressure and accumulated precipitation than that based on daily data (Table 1). Major reasons for these differences in performance may be the lower density of the network (22 vs 47) sites and location of sites cf., [77].

Wind-speed errors, according to skill-scores, may be associated with the boundary conditions and misrepresentation of terrain height and surface heterogeneity; model performance is better in coastal areas than for sites inland that are influenced strongly by terrain-induced turbulence, channeling of winds and other effects related to mountainous terrain. 
Table 1. Quantitative Skill-Scores Determined Over All Available Data of the Entire Episode for the Control Simulations: Bias, Standard Deviation of Error (SDE), Root Mean Square Error (RMSE), and Correlation Coefficient (R)

\begin{tabular}{|c|c|c|c|c|c|c|c|c|}
\hline & Bias & SDE & RMSE & R & Bias & SDE & RMSE & R \\
\hline & \multicolumn{3}{|c|}{ Hourly Values } & \multicolumn{5}{|c|}{ Daily Mean Values } \\
\hline \hline Pressure & $0.0 \mathrm{hPa}$ & $0.6 \mathrm{hPa}$ & $0.6 \mathrm{hPa}$ & 0.438 & $-1.1 \mathrm{hPa}$ & $4.0 \mathrm{hPa}$ & $4.5 \mathrm{hPa}$ & 0.407 \\
\hline Wind Speed & $0.0 \mathrm{~m} / \mathrm{s}$ & $0.6 \mathrm{~m} / \mathrm{s}$ & $0.6 \mathrm{~m} / \mathrm{s}$ & 0.658 & $1.1 \mathrm{~m} / \mathrm{s}$ & $2.7 \mathrm{~m} / \mathrm{s}$ & $3.1 \mathrm{~m} / \mathrm{s}$ & 0.635 \\
\hline Temperature & $0.0^{\circ} \mathrm{C}$ & $0.8^{\circ} \mathrm{C}$ & $0.9^{\circ} \mathrm{C}$ & 0.715 & $0.9^{\circ} \mathrm{C}$ & $5.2^{\circ} \mathrm{C}$ & $5.5^{\circ} \mathrm{C}$ & 0.668 \\
\hline Daily maximum temperature & - & - & - & - & $0.1^{\circ} \mathrm{C}$ & $3.5^{\circ} \mathrm{C}$ & $4.0^{\circ} \mathrm{C}$ & 0.752 \\
\hline Daily minimum temperature & - & - & - & - & $2.1^{\circ} \mathrm{C}$ & $4.8^{\circ} \mathrm{C}$ & $5.5^{\circ} \mathrm{C}$ & 0.597 \\
\hline Dew-point temperature & $0.1^{\circ} \mathrm{C}$ & $0.7^{\circ} \mathrm{C}$ & $0.7^{\circ} \mathrm{C}$ & 0.529 & $2.8^{\circ} \mathrm{C}$ & $5.5^{\circ} \mathrm{C}$ & $6.5^{\circ} \mathrm{C}$ & 0.475 \\
\hline Accumulated precipitation & $0.0 \mathrm{~mm}$ & $0.0 \mathrm{~mm}$ & $0.0 \mathrm{~mm}$ & -0.130 & $1.0 \mathrm{~mm}$ & $1.5 \mathrm{~mm}$ & $2.4 \mathrm{~mm}$ & 0.327 \\
\hline
\end{tabular}

Note that skill-scores for daily maximum and minimum temperature include also data from the 22 sites with hourly data; daily accumulated precipitation includes also the daily accumulated sums from the 22 sites with hourly data, i.e. data from 47 sites.

Table 2. Categorical Skill-Scores Determined Over All Available Data of the Entire Episode for the Control Simulations: Threat-Score (TS), Accuracy (A), Heidke Skill-Score (HSS), and Probability of Detection (PoD)

\begin{tabular}{|c|c|c|c|c|}
\hline & TS (\%) & A (\%) & HSS & PoD (\%) \\
\hline \hline Hourly precipitation & 10 & 90 & 0.1 & 40 \\
\hline Daily precipitation & 10 & 90 & 0.5 & 90 \\
\hline Cloud Existence & 40 & 60 & 0.1 & 30 \\
\hline
\end{tabular}

Note that skill-scores for daily precipitation include also daily averages built based on the 22 sites with hourly data, i.e. data from 47 sites.

Generally, WRF has some difficulties capturing the width of the diurnal cycle of $2 \mathrm{~m}$-temperature and $2 \mathrm{~m}$ dewpoint temperature see also [43]. This shortcoming may indicate that WRF does not capture surface fluxes well, which can be related to a misinterpretation of surface processes, terrain height, snow cover, or downward radiation fluxes because of cloud-cover misrepresentation. The boundary conditions may also affect the simulation of the diurnal cycle.

Generally, cloudiness is delayed and slightly underestimated, which is a combined result from assuming zero cloud and precipitation mixing ratios at the start of the simulations and at the inflow boundaries of the model domain. Consequently, WRF has some difficulties in capturing the temporal evolution of hourly precipitation events. Nevertheless, precipitation errors are acceptable when evaluated by daily-accumulated data. Some errors in simulated daily-accumulated precipitation can be associated with catch deficits e.g., [78, 79] and poor regional representation by available observation sites (Fig. 2); cf. [77].

Categorical scores determined for the episode indicate good performance of WRF with respect to precipitation simulation (Table 2). Accuracy is about $90 \%$ for both daily and hourly precipitation. Accuracy, however, can be misleading because the most common category (i.e., no or low precipitation rate) heavily influences accuracy. The threat-score of $10 \%$ places the forecasts in the lower performance range of modern NWP models as typical threatscores for a $24 \mathrm{~h}$-simulation and precipitation thresholds $\geq$ $0.25 \mathrm{~mm} / \mathrm{d}$ are about $20 \%$ e.g., [54]. The probability of detection (PoD) only considers correctly simulated events and incorrectly simulated events. Typically, PoD range between 72 and $96 \%$ for precipitation $\geq 0.25 \mathrm{~mm} / \mathrm{d}$ e.g., [55]. If accuracy and $\mathrm{PoD}$ are close in value, one can expect both scores to be fairly representative of the precipitation performance. Daily precipitation has a PoD and accuracy of $90 \%$, while for hourly precipitation PoD and accuracy amount to $40 \%$ and $90 \%$, respectively. These findings indicate that WRF well simulates daily-accumulated precipitation and acceptably represents the precipitation events. When looking at hourly data, errors result from forecasting the timing (onset and duration of precipitation) and/or intensity of precipitation. These errors may cancel each other out when looking at daily-accumulated precipitation rates. According to the Heidke skill-score (HSS; Table 2), the simulations of precipitation events exceed random chance for both hourly and daily events.

On average over the episode and all sites, accuracy and threat-score of cloud existence amount to $60 \%$ and $40 \%$, respectively. Overcast and clear days generally have high values of threat scores and accuracy. The threat scores and accuracy are lower on partly cloudy days than days with overcast because any "misses" lower the score. Accuracy is about twice as high as the PoD. This finding means that accuracy is less representative of correct performance with respect to simulating cloudiness because correctly simulated non-cloudy events affect accuracy positively. The HSS indicate that correctly simulated "cloud existence" is better than random chance.

Comparison of simulated cloudiness with AVHRR data shows that WRF broadly to very well captures the cloud distribution (Fig. 4). Due to errors in other quantities, WRF occasionally simulates the timing and positioning of the clouds delayed or ahead in time or slightly off in space. For satellite passages close to the onset of a simulation, WRF underestimates cloud extent because WRF starts with zero cloud and precipitation mixing ratios. This behavior is consistent with low categorical scores of cloud existence at the beginning of simulations. Due to the relatively coarse spacing at upper levels, WRF misses some cirrus clouds; 
WRF well simulates mid-level and low-level clouds (Fig. 4). This behavior is similar to that found in studies evaluating MM4 and MM5 simulated clouds by using AVHRR data e.g., [80, 81]. Based on the precipitation evaluation and comparison to satellite data, we conclude that WRF describes cloud and precipitation processes with an acceptable degree of accuracy.

Skill scores determined for $24 \mathrm{~h}$ for the day before the eruption are of same magnitude than those determined for $24 \mathrm{~h}$-periods for the days with volcanic perturbations. Thus, we cannot assess the volcanic impacts on the atmosphere by the available surface observations. The sites are too far downwind of the volcano except for the buoy offshore of Augustine Island (dot next to Augustine Island in Fig. 2). The buoy was upwind of or parallel to the volcanic plumes most of the times.

In the immediate downwind of the volcano (20 to 30 $\mathrm{km}$ ), cloud and precipitation mixing ratios, vertical wind speed and temperature have locally significant differences among the 16 simulations (as discussed later). However, quantitative skill-scores obtained for the 15 simulations with various volcanic forcing differ from those of the control simulation by less than $\pm 0.1 \mathrm{~K}, 0.1 \mathrm{~mm} / \mathrm{d}, 0.1 \mathrm{hPa}, 0.01 \mathrm{~m} / \mathrm{s}$ and 0.01 . This result indicates that the volcanic forcing has no impact on these quantities on the medium range meteorology, where the sites are located (Fig. 2). In the area of the land sites, the ANOVA and the Student $t$-tests indicate no statistically significant differences between the 15 simulations with the various volcanic scenarios and the control simulation. These findings well agree with the results of the comparison of the performance before and after onset of the eruption discussed above.

\subsection{General Findings}

The ANOVA indicates locally significant volcanic impacts on, as well as interactions among volcanic impacts on cloud and precipitation formation. These influences and interactions clearly depend on emission strength and a favorable meteorological situation. They occur most frequently during days with widespread cloudiness and frequent precipitation events. January 24 through February 2 experience the most significant volcanic impacts on clouds and precipitation (Table 3). During this time widespread cloudiness and frequent precipitation events governed the area. January 21 and 22 experienced overcast skies and widespread precipitation events across most of the domain as well, but had less variable assumed forcing (Fig. 3). For these days, the ANOVA indicates very few quantities experiencing locally significant impacts and few interactions among volcanic effects. January 11 to 12 and 15 experience the least significant impact or interaction among impacts of the volcanic factors on meteorological quantities. During these days high pressure dominated the region. Indirect aerosol effects, riming-indirect effects, semi-direct effects, and glaciation indirect aerosol effects remain relatively small, if they occur at all, because of the low ambient watervapor content. However, the impact of temperature-albedo feedback due to decreased albedo in response to ashfall becomes more important during the clearer high-pressure conditions than under the cloudy low-pressure conditions. In our study, the impact is not large because of the short daylight (about $5 \mathrm{~h}$ and $4 \mathrm{~h}$ in the south and north of the domain, respectively). At this time of the year the radiation balance is typically negative. Since our study was performed for winter, one has to expect that shortwave effects are much smaller than they could be during the white nights of summer. Moreover, in summer ashfall most likely leads to an overall increase in albedo as the ash is lighter than most of the dark vegetated surfaces. Consequently, ashfall would have an opposite effect on near-surface temperatures than ashfall on relatively brighter snow-covered surfaces.

Volcanic factors alter clouds and precipitation through three main mechanisms: increased buoyancy, increase in $\mathrm{CCN} / \mathrm{IN}$ numbers, and combined effects. Increased buoyancy can directly result from volcanic heat release and/or water vapor release (e.g., Figs. 5-9) or indirectly because of indirect aerosol effects, thermodynamic and radiative effects. For the scenarios applying just one aspect of the volcanic factors alone (Hvca, hVca, hvCa, hvcA) we find pronounced direct responses immediately downwind of the volcano: enhanced cloudiness due to volcanic watervapor release (e.g., Fig. 7) or volcanic aerosol release on relatively humid days, increased surface heating and enhanced buoyancy due to ashfall, and enhanced buoyancy in response to heat release (e.g., Fig. 6). When volcanic factors occur concurrently, responses may affect different levels in the atmosphere than for the individual factors alone (e.g., Figs. 8-10). Note that the cross-sections show daily averages. Since wind direction changes during the day or varies, differences in quantities may occur on both sides of the island even if a wind direction dominates.

Generally, our results show that precipitation changes in response to the volcanic impacts lead to further precipitation changes downwind (e.g., Fig. 11). These secondary responses result from changes caused in response to the volcanic factors. Downwind of the volcano, two different patterns may occur. If the volcanic factors enhance precipitation, the atmospheric water load will be deposited closer to the volcano and less precipitation will occur downwind as compared to the control simulation. The analysis of cloud and ice mixing ratios shows that precipitation increases due to glaciation indirect aerosol effects and increased efficiency of the Findeisen-BergeronWegener effect. Since a substantial water load has been removed close to the volcano, less precipitation occurs further downwind. If precipitation decreases close to the volcano, typically precipitation will be enhanced downwind of the area with decreased precipitation. Investigation of the cloud and ice mixing ratios suggests indirect aerosol effects as the main reason for the modified precipitation pattern. The water load is transported farther before, precipitation-size particles form.

On some days substantial wind shear exists in the upper troposphere. Thus, sometimes when the volcanic impacts cause ice particles to form higher in the atmosphere than without volcanic factors, these ice particles may exist at a level wherein wind comes from a different direction than in the lower atmosphere. As these ice particles settle, they may cause differences in precipitation that seem to be upwind of the volcano (e.g., Fig. 11).

The ANOVA suggests that significant changes of a meteorological quantity in response to two individual 
Table 3. Days with Significant Changes in or Interaction of Factors for Air Temperature, T, Vertical Velocity, w, Specific Humidity, $q_{v}$, Cloud Water Mixing Ratio, $q_{c}$, Ice Mixing Ratio, $q_{i}$, and Precipitation, $P$, for the Various Simulations

\begin{tabular}{|c|c|c|c|c|c|c|}
\hline Simulation & $\mathbf{T}$ & $\mathbf{W}$ & $\mathbf{q}_{\mathbf{v}}$ & $\mathbf{q}_{\mathbf{c}}$ & $\mathbf{q}_{\mathbf{i}}$ & $\mathbf{P}$ \\
\hline \hline $\mathrm{Hvca}$ & $15,21,25,30,33$ & $25,29,30,33$ & $25,29,30,33$ & $25,29,30,33$ & $25,29,30,33$ & $15,21,25,30,33$ \\
\hline $\mathrm{hVca}$ & $11,15,25,29,33$ & $12,15,17,25,29,33$ & $12,15,17,21,25,29,33$ & $11,12,15,17,25,29,33$ & $11,12,15,17,21,25,29,33$ & $11,12,15,17,21,25,29,33$ \\
\hline $\mathrm{hvCa}$ & $12,21,25,29,30,33$ & $12,15,17,25,29,30,33$ & $15,17,25,29,33$ & $12,15,17,25,29,33$ & $12,29,33$ & $12,17,21,25$ \\
\hline $\mathrm{hvcA}$ & & & & & 17 & 17 \\
\hline $\mathrm{HVca}$ & $15,21,30,33$ & 25,30 & $25,29,30,33$ & $25,29,30,33$ & $25,29,30,33$ & $21,25,30,33$ \\
\hline $\mathrm{HvCa}$ & $25,29,30,33$ & $25,29,30,33$ & $25,29,33$ & $25,29,30,33$ & $25,29,30,33$ & $21,25,29,30,33$ \\
\hline $\mathrm{HvcA}$ & & & & & 25 \\
\hline $\mathrm{hVCa}$ & $11,12,29$ & $12,15,25,29,30,33$ & $12,15,17,25,29,33$ & $11,12,17,25,29,30,33$ & $12,15,17,25,29,30,33$ & $12,17,21,25,30,33$ \\
\hline $\mathrm{hvCA}$ & $21,29,30$ & $25,29,30,33$ & $25,29,30,33$ & $25,29,33$ & $25,29,30,33$ & $21,25,30,33$ \\
\hline $\mathrm{hVcA}$ & 30 & 30 & & 30 & & 30 \\
\hline $\mathrm{HVCa}$ & 21,29 & $25,29,33$ & $25,29,33$ & $25,29,33$ & $25,29,33$ & $15,21,29,33$ \\
\hline HVcA & 30 & 30 & 30 & 30 & & 25,30 \\
\hline
\end{tabular}

Days are given as days of year (Julian days).

volcanic factors do not automatically mean significant interactions of effects with respect to that quantity when the two factors occur concurrently (Table 3 ). When volcanic factors occur concurrently, various processes may diminish or enhance the impacts of the individual factors.

Release of heat, water vapor and/or aerosols affect the onset of cloud formation and precipitation as well as the temporal evolution of clouds and precipitation, temperature, and vertical motions. Thus, temporally much higher/lower values occur in the simulations with volcanic perturbations than in the control simulations. This finding suggests that during volcanic eruptions any forecasts of vertical motions, cloud conditions and precipitation will be most likely inaccurate in the immediate vicinity of the volcano due to the unknown volcanic forcing.

\subsection{Effect of Heat Release}

On most days, the buoyancy effect in response to volcanic heat release (Hvca) changes precipitation notably, but not always statistically significantly (Table $\mathbf{3}$ ). On days with significant precipitation changes, volcanic heat release significantly changes at least two of the following quantities: temperature, water vapor, cloud and ice mixing ratios, and vertical velocity (Table 3 ). Note that here vertical velocity refers to the grid-cell average value as the model does not resolve individual updrafts.

Precipitation either decreases or increases depending on the processes becoming dominant. On cloudy days, volcanic heat release can either cause a rise in cloud condensation and/or cloud top levels (enhanced cloudiness) or reduce cloudiness as compared to the undisturbed case. The directions of the changes depend on the ambient temperature and moisture conditions. Any increase in temperature requires a logarithmic increase in water vapor for saturation to occur. Thus, at the same height and ambient water-vapor amount, saturation may occur at the lower original temperature in the control simulation, but not at the higher temperature of Hvca. Consequently, cloud bases may rise or no clouds may form. Alternatively, the heat release and associated increased buoyancy can transport moist air to higher levels as compared to the control simulation increasing cloud top heights. Ice sedimentation into lower levels enhances the Findeisen-Bergeron-Wegener process. Consequently, precipitation formation becomes more efficient in Hvca than the control simulation and accumulated precipitation significantly increases.

On January 25, for instance, volcanic heat release significantly increased the near-surface air temperatures (temporally up to $1.9 \mathrm{~K}$ ), precipitation (temporally up to 0.1 $\mathrm{mm} / \mathrm{h}$ ), and vertical motion (up to $1.8 \mathrm{~cm} / \mathrm{s}$ on daily average) from added buoyancy downwind of the volcano (Fig. 6d). On January 25, the Findeisen-Bergeron-Wegener process gained importance in response to heat release. The larger ice particles have higher terminal velocities and sediment out faster than in the control simulation leading to reduced ice mixing ratios in the lower ABL $50 \mathrm{~km}$ or so downwind of the volcano (Fig. 6c).

January 30 is an example of decreased cloudiness and precipitation. At times the heat release significantly influenced the near-surface temperature, precipitation, cloud mixing ratios, and vertical velocity up to $1.5 \mathrm{~K},-0.1 \mathrm{~mm} / \mathrm{h}$, $0.13 \mathrm{~g} / \mathrm{kg}$, and $9.8 \mathrm{~cm} / \mathrm{s}$, respectively. Water-vapor mixing ratio decreased by a total of $0.14 \mathrm{~g} / \mathrm{kg}$ downwind of Augustine Volcano. In contrast to the conditions of January 25 , not enough humidity existed at the higher levels and not enough moisture was transported into these levels for saturation and increased cloud top heights to occur. February 2 was another example of volcanic heat release causing local decreases in accumulated precipitation (temporally up to 1.4 $\mathrm{mm} / \mathrm{h}$ ).

In summary, enhanced buoyancy due to volcanic heat release will only increase precipitation if the decrease in cloud particle formation at lower levels due to the effect of increased saturation mixing ratios is compensated for by condensation and/or deposition of advected water vapor at 


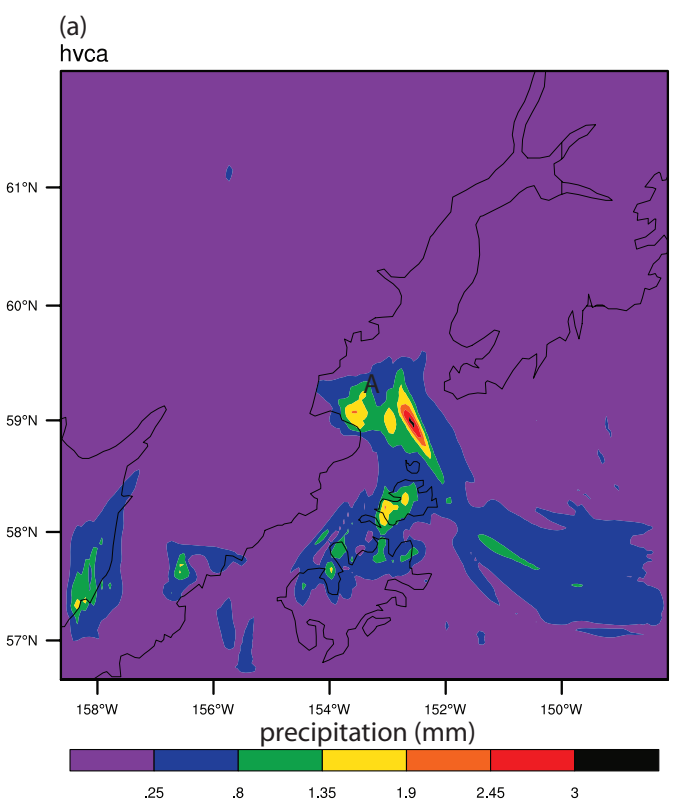

(c)

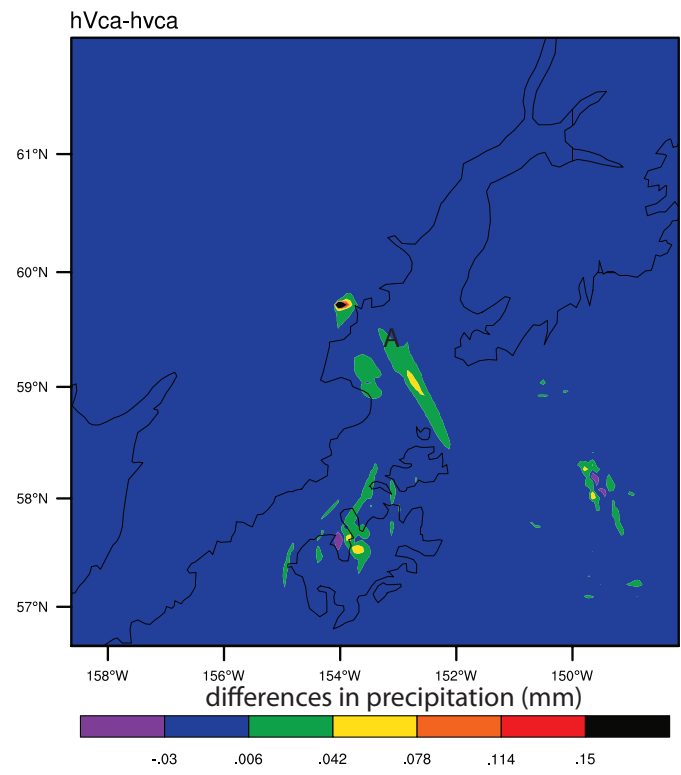

(b)

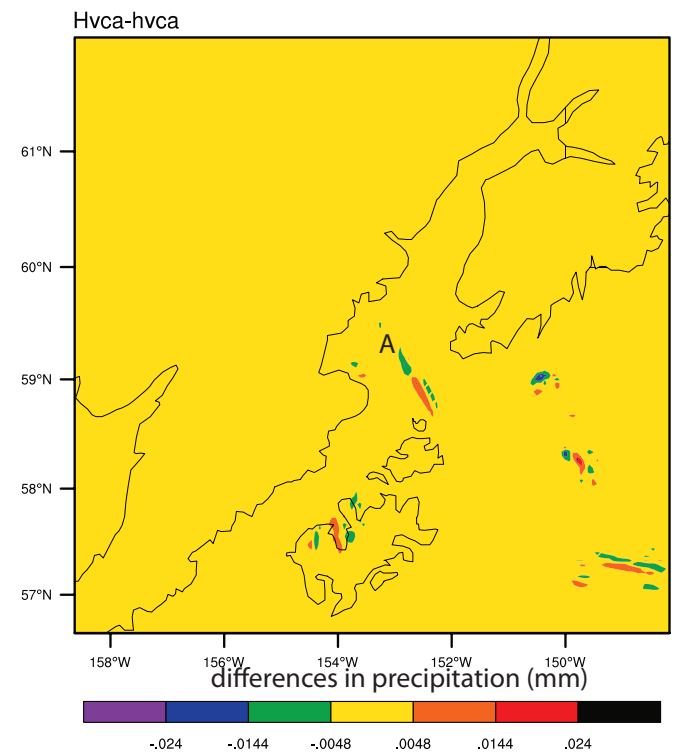

(d)

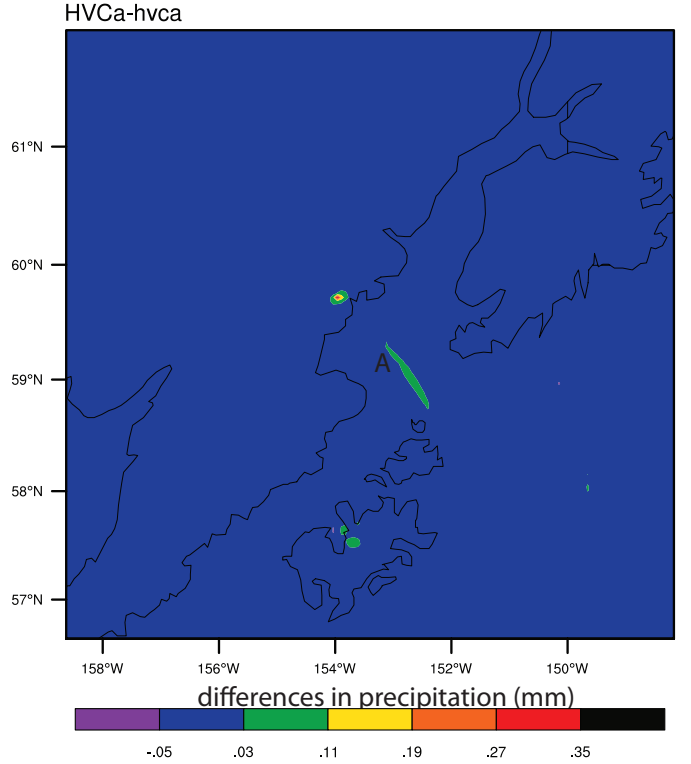

Fig. (11). Horizontal distribution of (a) 24h-accumulated precipitation on January 25, 2006, and differences in 24-h accumulated precipitation between the simulation with (b) heat release alone (Hvca) and the control simulation (hvca), (c) water vapor release alone (hVca) and the control simulation (hvca), (d) concurrent heat, water vapor and aerosol release (HVCa) and the control simulation (hvca). Note that the scales differ among the various parts of the figure for better visualization of differences. The scale is spread between the minimum and maximum difference occurring for the comparison of the respective two simulations, i.e. gives the maximum differences for this respective day.

higher atmospheric levels than otherwise would have been reached.

\subsection{Effect of Water Vapor Release}

Volcanic water-vapor release alone (hVca) marginally impacts clouds and precipitation when it is small, and on days with calm, dry regional weather (Table 3). On January 30, for instance, the area southeast of Augustine Volcano was relatively dry and the additional water vapor was not sufficient to cause condensation. On relatively humid days, however, water-vapor release has the largest impact on weather out of all the volcanic factors and their combination scenarios. On these days, volcanic water-vapor release alone significantly influences specific humidity, temperature, vertical velocity, cloud-water and ice mixing ratios (Table 3). In response to volcanic water-vapor release precipitation increases significantly and as much as $51.7 \mathrm{~mm}$ accumulated over the 24 day period. Except for January 11, all days with significant precipitation changes also experience significant changes in other quantities (Table 3).

The absence of an overall pattern of significant changes suggests differences in the effectiveness of various processes. On humid days, additional water vapor means supersaturation can be more easily reached and/or more water vapor is available for condensation/deposition. Cloud- 
droplet and ice-particle size grows and precipitation formation efficiency increases (Fig. 11c).

Release of latent heat during condensation/ deposition increases buoyancy and vertical velocity (e.g., Fig. 7d). These ascending air parcels reach higher levels than parcels without the volcanic water vapor (Fig. 7c). Here, the likelihood for ice formation increases, and riming and the Findeisen-Bergeron-Wegener process gain importance. Water vapor is incorporated into the precipitation formation process at lower saturation vapor pressure than without the volcanic water-vapor release.

In Polar Regions, radiative cooling drives near-surface air temperatures because it dominates the surface heat exchange when compared to the limited hours and low actinic fluxes of incoming solar radiation. Thus, before onset of precipitation, the enhanced cloudiness further increases near-surface temperatures (temporally up to $1.9 \mathrm{~K}$ ) and buoyancy downwind of the volcano. A positive feedback is established until precipitation onset.

An example of this positive enhancement occurs on January 25, when volcanic water vapor release caused temporally statistically-significant temperature, vertical velocity and precipitation increases of up to $0.5 \mathrm{~K}, 11 \mathrm{~cm} / \mathrm{s}$ and $1.1 . \mathrm{mm} / \mathrm{h}$ as compared to the control simulation. Above the volcano, at higher levels within the cloud, temperature increases are due to latent heat releases, while about $30 \mathrm{~km}$ downwind of the volcano, they relate to enhanced cloudiness (e.g., Fig. 7a). Above the volcano, below cloud base, temperature decreases due to increases in evaporative cooling caused by enhanced ice-particle concentrations falling into and sublimating in that layer (Fig. 7a, c). The upper part of the cloud extends far downwind (up to $80 \mathrm{~km}$ ) leading to notable changes there (Fig. 7c). In summary, volcanic water-vapor release increases the amount of precipitation per event (Fig. 11c).

\subsection{Effect of Aerosol Release}

On relatively dry days, volcanic aerosol release (hvCa) marginally impacts cloud and precipitation formation because the water-vapor amount stays below the saturation water vapor value. Volcanic aerosol release significantly affects temperature, vertical velocity, water vapor and cloud mixing ratios and precipitation on relatively humid days (Table 3) as the indirect aerosol effect reduces overall precipitation. In general, significant effects of aerosols remain localized over Augustine Volcano (therefore not shown).

\subsection{Effect of Ashfall}

Ashfall (hvcA) notably affects temperature, vertical velocity, water vapor, cloud and ice mixing ratios, as well as precipitation on cloudy days. However, the temperaturealbedo feedback in response to ashfall only alters ice mixing ratios and precipitation significantly on January 17 . On January 17, the ash plume moved north and was unusual (water rich) compared to other days and the split-window signal in the AVHRR data was very poor compared to the other days. Such weak split-window signals often indicate that condensation of water vapor on ash particles occurred because coarse particles have a weak contrast to the background temperature. For these effects to be found in satellite data the atmosphere must be favorable for condensation, and transport and sedimentation of coarse particles [82]. Note that the split-window technique permits for detecting plumes. In this method, the data from AVHRR channel 5 is subtracted from that of channel 4 data. Typically, the spectral signatures of meteorological clouds differ very little between channels 4 and 5, while volcanic ash clouds result in brightness temperature differences less than zero. This technique is generally useful, but can mistake dense or opaque clouds and storm fronts for ash plumes.

January 30 is an example of very little ashfall impact on local weather. In the ABL, the wind direction was from north-northeast and the plume went mainly out over the open ocean with the exception of Kodiak Island. Low-level cloud cover surrounded Augustine Island on January 30. The plume of aerosols, water vapor, and ash was ejected above the cloud layer and traveled southwards, away from the cloudy areas and is simulated as such. Since only Kodiak Island received some ashfall, ashfall reduced albedo only in a small area.

\subsection{Lower Order Interaction Effects}

The ANOVA indicates significant interaction between factors for $\mathrm{hVCa}, \mathrm{HvCa}, \mathrm{hvCA}$, and $\mathrm{HVca}$ on many days (Table 3). In all these cases, these interactions result in temperature increases downwind of Augustine Volcano, but for different reasons and at different levels (e.g., Figs. 8-10). In $\mathrm{HvCa}$ and $\mathrm{HVca}$, the volcanic heat release directly causes the temperature increase, while in $\mathrm{hVCa}$ and hvCA indirect aerosol and radiative effects cause the temperature increase below and in cloud levels (e.g., Figs. 8-10). In all four scenarios, release of latent heat during condensation and/or deposition of water vapor contribute to temperature increase within clouds, but at different heights.

Generally, HVca simulations show increased buoyancy and vertical motion as compared to the control simulation (e.g., Fig. 9d; Table 3). Transport of moisture to higher levels than in the control simulation triggers the FindeisenBergeron-Wegener process (e.g., Fig. 9b, c). The enhanced efficiency of precipitation formation and additional water vapor yield increased precipitation as compared to the control simulation. On January 25, precipitation increases temporally up to $1.2 \mathrm{~mm} / \mathrm{h}$

Concurrent water vapor and heat release (HVca) cause significant interactions for temperature on various days (Table 3). Significant interactions for water vapor, cloud and ice mixing ratios do not necessarily cause significant interactions for precipitation. On relatively dry days with stable conditions like January 29, the additional heat and water vapor initiate significant interaction of effects on water vapor and cloud and ice mixing ratios, however, hardly impact the existing low efficiency of precipitation formation and hence precipitation amount. Interestingly, significant interaction of the effects of concurrent water vapor and heat release with precipitation occurs for January 21 when only temperature also experiences significant interaction effects. Obviously, sufficient impacts of the concurrent volcanic effects on the ice phase via Findeisen-Bergeron-Wegener process, glaciation and riming effects are required to cause significant interaction of effects for precipitation. 
Concurrent water vapor and aerosol release (hVCa) more often change local weather relevant quantities significantly than aerosol release alone (hvCa). The former leads to significant interactions with temperature, water vapor, cloud and ice mixing ratios, vertical velocity and precipitation (Table 3). Obviously, interaction effects with temperature and vertical velocity are not required for significant interaction effects with precipitation to occur. They are just consequences of thermodynamic and radiative effects and interaction cloud-microphysics dynamics in response to the primary indirect aerosol effects.

Concurrent release of water vapor and aerosols ( $\mathrm{hVCa}$ ) may diminish or enhance the individual effects of these volcanic factors. The amount of aerosol and water vapor release and the ambient water vapor mixing ratio determine whether precipitation increases or decreases. Precipitation will enhance if the additional water vapor compensates the indirect aerosol effect due to enhanced CCN/IN numbers so that cloud and/or ice particles grow larger than those of the control simulations. January 25 is an example of such compensation. In the upper part of the cloud, ice-mixing ratios are enhanced and initiate a more effective FindeisenBergeron-Wegener process (e.g., Fig. 8c). Precipitation will decrease if the additional water vapor fails to compensate the indirect aerosol effect due to enhanced $\mathrm{CCN} / \mathrm{IN}$ numbers and cloud and/or ice particles remain smaller than in the control simulations. If the concurrent releases lead to similar cloud/ice particle sizes as in the control simulation, cloud and ice particle concentrations notably change, but no significant interaction effects occur for precipitation.

January 30 is an example of increased precipitation (temporally as much as $4.9 \mathrm{~mm} / \mathrm{h}$ ) close to the volcano. A similar case occurs on January 25, but with less extreme consequences for total accumulated precipitation (therefore not shown) despite temporally precipitation differs as much as $1.1 \mathrm{~mm} / \mathrm{h}$.

Indirect aerosol and thermodynamic effects in response to concurrent heat and aerosol release ( $\mathrm{HvCa}$ ) significantly interact for temperature, vertical velocity, water vapor, ice and cloud mixing ratios, and precipitation (Table 3 ). Interactions between aerosol and heat effects amplify the retardation of cloud- and ice-particle formation and reduce the efficiency of precipitation formation and amount. Temperature increases are mainly due to the heat release (compare e.g., Figs. 6a, 10a). The aerosol release occurring concurrent to the heat release affects the ice mixing ratios the strongest (e.g., Figs. 6c, 10c). The indirect aerosol effect strongly modifies the Findeisen-Bergeron-Wegener effect.

Ashfall only significantly influences atmospheric variables when combined with aerosol release (hvCA; Table 3). The indirect aerosol effect enhances optical thickness of the clouds in hvCA. The resulting radiative effect and the temperature-albedo effect in response to ashfall both lead to a warmer $\mathrm{ABL}$ than in the control simulation. Interaction effects between aerosol radiative and ashfall effects significantly impact temperature, vertical velocity, water vapor and ice mixing ratios downwind of the volcano. Obviously in hvCA, significant interaction effects with cloud water mixing ratios are not required for significant interaction with precipitation to occur, but may exist. The concurrently occurring factors can also cause significant interaction effects with precipitation if only temperature experiences significant interaction effects. The synoptic situation and amount of aerosol emitted are determinant for whether or not these interaction effects occur.

\subsection{Higher Order Effects}

According to the ANOVA results, most quantities investigated experience insignificant higher-order interactions on almost all days. This means that processes induced by any individual volcanic effect in combination do not significantly enhance or counteract themselves in their efficiency. The only exceptions are HVCa on January 25 and HVcA on January 30 . On January 25, simultaneous release of heat, water vapor and aerosols (HVCa) causes significant interaction effects for all quantities investigated except precipitation and temperature. On January 30, simultaneous ashfall, water vapor, and heat ( $\mathrm{HVcA})$ increases precipitation notably (temporally as much as $0.9 \mathrm{~mm} / \mathrm{h}$ and significant secondary interaction effects with temperature, precipitation, cloud and ice mixing ratios occur downwind of Augustine Volcano.

\section{CONCLUSION}

A modified version of WRF was used to theoretically examine (1) the impact of high-latitude moderate volcanic eruptions on clouds and precipitation and (2) how the effects in response to heat, aerosols and water vapor releases and reduced surface albedo interact with each other when modifying atmospheric processes. To achieve these goals, 16 simulations per day were performed assuming simplified volcanic emission scenarios: one control simulation (no volcanic factors, hvca), four simulations each with different individual volcanic factor enabled (Hvca heat release, $\mathrm{hVca}$ water-vapor release, hvCa aerosol release, hvcA ashfall), and eleven simulations for all possible combinations of factors.

WRF's performance was evaluated by observations from 22 sites with hourly reported data and 25 sites with daily reported data as well as satellite data to assess the reliability of WRF forecasts during an episode of unknown external forcing. All 16 simulations adequately represent the synoptic situation. Skill-scores obtained for the control simulations and the 15 unperturbed simulations hardly differ from each other. Skill for the day before the eruption is similar to that of days during the eruption episode. Both these results indicate that the volcanic forcing has no impact on the medium range at the location of the sites (Fig. 2) despite in the immediate downwind direction of the volcano (20-30 $\mathrm{km}$ ), cloud and precipitation mixing ratios, vertical wind speed and temperature locally are significantly different among the 16 simulations.

On average, WRF overestimates $2 \mathrm{~m}$ temperature, dewpoint temperature, $10 \mathrm{~m}$ wind speed, and precipitation by 0.9 $\mathrm{K}, 2.8 \mathrm{~K}, 1.1 \mathrm{~m} / \mathrm{s}$, and $1 \mathrm{~mm} / \mathrm{d}$, respectively; WRF generally underestimates daily mean sea-level pressure $(-1.1 \mathrm{hPa})$ and cloud existence for the episode considered here. These skillscores are in the range of other modern NWP models. Together with the results from the ANOVA, one can conclude that at a distance of $>50 \mathrm{~km}$ from an erupting volcano WRF data is well suited to be used in this sub-arctic region even when moderate unknown volcanic forcing may exist due to a volcanic eruption within the region. 
The impact of volcanic eruptions on local weather and the temporal and spatial cloud and precipitation distributions will depend on the emission strength, volcanic factors, interaction among impacts of factors if they occur concurrently, and the broader synoptic-scale meteorological environment. The ANOVA shows that the assumed volcanic scenarios have the greatest statistically significant (at $95 \%$ or higher confidence level) impact on clouds and precipitation on relatively humid days. Significant changes in cloud- and precipitation-relevant quantities occur in the downwind close to the volcano $(<50 \mathrm{~km})$ for water vapor ( $\mathrm{hVca})$, heat (Hvca), and aerosol (hvCa) release. Depending on the meteorological conditions volcanic heat release can either yield a rise of cloud condensation and/or cloud top levels or reduce cloudiness.

In the downwind close to the volcano, significant interaction of volcanic effects on cloud- and precipitationrelevant quantities also exist in response to concurrent water vapor and aerosol release ( $\mathrm{hVCa}$ ), heat and aerosol release $(\mathrm{HvCa})$, ashfall and aerosol release (hvCA), and heat and water vapor release ( $\mathrm{HVca}$ ). A range of possible mechanisms leading to interaction effects has been identified. For concurrent water vapor and aerosol release $(\mathrm{hVCa})$, precipitation will enhance if the additional water vapor compensates the indirect aerosol effect caused by the aerosol release. Precipitation will decrease otherwise. Indirect aerosol effects and heat effects in response to concurrent heat and aerosol release ( $\mathrm{HvCa}$ ) amplify the retardation of cloud and ice particle growth and reduce the efficiency of precipitation formation and amount. The non-linear impacts of heat and water-vapor release on the ice phase strongly modify the rate of changes of ice microphysical processes related to the Findeisen-Bergeron-Wegener process, glaciation and riming effects when these volcanic factors occur concurrently (HVca).

Responses to volcanic factors may diminish or enhance the impacts of the individual factors when volcanic factors occur concurrently. Thus, significant changes of a meteorological quantity in response to two individual volcanic factors do not automatically mean that the concurrent existence of these volcanic factors will lead to significant interaction of effects for that quantity (Table 3 ).

The responses of clouds and precipitation to volcanic effects and the interactions among responses mean that routine NWP can face difficulties to forecast cloud and precipitation conditions close to volcanoes $(<50 \mathrm{~km})$ during volcanic eruptions because of the unknown volcanic emission scenario at the time of the forecast. Our investigation shows that the following modifications can be expected qualitatively on relatively humid days: strong concurrent emissions of water vapor and aerosols enhance precipitation in the farther downwind area, while aerosol emissions alone or weak water vapor and aerosol emission diminish precipitation in this area. The additional buoyancy in direct response to increased near-surface temperature due to radiative heat from the caldera or temperature-albedo feedback can lead to higher reaching clouds, and increased cloudiness and an overall increase in surface temperature due to reduced irradiation (positive feedback).

Observational and further theoretical work is required to gain understanding of the full range of interaction of effects in response to the various volcanic factors in more complex scenarios than the simple scenarios assumed here.

\section{ACKNOWLEDGEMENTS}

We thank U.S. Bhatt, M.S. Dhadly, R. Gens, G. Kramm, Z. Li, S.E. Porter, H.N.Q. Tran, T.T. Tran and the anonymous reviewers for fruitful discussions and K.L. Wallace for the ashfall data. This research was supported in part by an International Polar Year student fellowship (Project CIPY-16) through the Cooperative Institute for Arctic Research with funds from NOAA under cooperative agreement NA17RJ1224 with the University of Alaska; NSF under contracts ATM0232198, OPP0327664 and ARC0652838; and Teaching Alaskans Sharing Knowledge (TASK), a UAF extension of the NSF GK-12 fellowship program. Computational support was provided by NCAR and in part by a grant of HPC resources from the Arctic Region Supercomputing Center at the University of Alaska Fairbanks as part of the Department of Defense High Performance Computing Modernization Program.

\section{APPENDIX}

In general, each variable (e.g., precipitation, temperature) can be broken down into an overall mean, individual effects, interactions between effects, and error terms. Hence, the ANOVA linear model in terms of the sum of squares is defined as the total sum of squares for all factors (e.g., [58])

$$
S S_{T}=S S_{E}+\sum_{i} \sum_{j} \sum_{k} \sum_{m} S S_{i j k m}
$$

For higher order ANOVA designs (i.e. a large number of treatments to consider), each variable is summed up across the area of interest and time to obtain one replicate (e.g., [58]). Hence, one value exists per treatment, per variable, and per day. For unreplicated ANOVA designs, the error $S S_{E}$ is determined by plotting treatment estimates against their probability and assuming all non-significant treatments (characterized by a linear fit) as error [58]. The sum of squares $S S_{i j k m}$ is given by (e.g., [58])

$$
S S_{i j k m}=\frac{1}{2^{4}}\left(\text { Contrast }_{i j k m}\right)^{2}
$$

here $i, j, k$, and $m$ represent the two levels (on or off) of the volcanic factors radiative heat from the caldera, water vapor release, aerosol release, and ashfall, respectively. In calculating the

$$
\text { Contrast }_{i j k m}=(i+1)(j+1)(k+1)(m+1)
$$

treatments turned off are subtracted by 1 and those turned on are added to 1 [58]. Here, "1" represents the control simulation (hvca) where all volcanic factors are turned off. The tertiary interaction treatment, for example, reads

$$
\text { Contrast }_{H V C A}=(H-1)(V-1)(C-1)(A-1)
$$

which can be expanded to

$$
\begin{aligned}
& \text { Contrast }_{H V C A}=H V C A-H V C a-H V c A-H v C A-h V C A \\
& +h v C A+h V c A+H v c A+h V C a+H v C a+H V c a-H v c a \\
& -h V c a-h v C a-h v c A+1
\end{aligned}
$$


where the interaction treatments are represented by combined individual factors (e.g., $\mathrm{HVCa}, \mathrm{hVcA}$ ). In determining the contrast of a treatment, $\mathrm{i}, \mathrm{j}, \mathrm{k}$, and $\mathrm{m}$ represent the treatment, not the value (cf. [58]).

To test the null hypothesis, the sum of squares value is divided by the degrees of freedom to get the mean square MS. If the null hypothesis is true, the $M S_{i j k m}$ of the treatments analyzed and the standard deviation $\sigma^{2}$ fulfill (e.g., $[58])$

$$
M S_{i j k m}=\sigma^{2}
$$

Otherwise, an f-value is calculated as (e.g., [58])

$$
f_{\text {calc }}=\frac{M S_{i j k m}}{M S_{E}}
$$

to investigate the significance. If $\mathrm{f}_{\text {calc }}$ exceeds the expected $\mathrm{f}$ test value, we can reject the null hypothesis concluding that the respective volcanic treatment significantly affects the variable examined.

\section{REFERENCES}

[1] Robock A, Mass C. The Mount St. Helens volcanic eruption of 18 May 1980: large short-term surface temperature effects. Science 1982; 216: 628-30.

[2] Mass C, Robock A. The short-term influence of the Mount St. Helens volcanic eruption on surface temperature in the Northwest United States. Mon Wea Rev 1982; 110: 614-22.

[3] Robock A, Mao J. Winter warming from large volcanic eruptions. Geophys Res Lett 1992; 12: 2405-08.

[4] Robock A, Mao J. The volcanic signal in surface temperature observations. J Climate 1995; 8: 1086-103.

[5] Kirchner I, Stenchikov GL, Graf HF, Robock A, Antuña JC. Climate model simulation of winter warming and summer cooling following the 1991 Mount Pinatubo volcanic eruption. J Geophys Res 1999; 104D: 19039-56.

[6] Oman L, Robock A, Stenchikov G, Schmidt GA, Ruedy R. Climatic response to high-latitude volcanic eruptions. J Geophys Res 2005; 110:D13103.

[7] Wigley TML, Ammann CM, Santer BD, Raper SCB. Effect of climate sensitivity on the response to volcanic forcing. J Geophys Res 2005; 110: D09107.

[8] Pruppacher HR, Klett JD. Microphysics of clouds and precipitation. $2^{\text {nd }}$ ed. Netherlands: Kluwer Academic Publishers 1997.

[9] Rogers RR, Yau MK. Short course in cloud physics; ButterworthHeinemann. Oxford, UK: Elsevier Science 1989.

[10] Ruddiman WF. Earth's climate. past and future. USA: W.H. Freeman and Company 2001: p. 465.

[11] Durant AJ, Shaw RA, Rose WI, Mi Y, Ernst GGJ. Ice nucleation and overseeding of ice in volcanic clouds. J Geophys Res 2008; 113:D09206.

[12] Lohmann U, Kärcher B, Timmereck C. Impact of the Mount Pinatubo eruption on cirrus clouds formed by homogeneous freezing in the ECHAM4 GCM. J Geophys Res 2003; 108D18, 4568 .

[13] Herzog M, Graf HF, Textor C, Oberhuber JM. The effect of phase changes of water on the development of volcanic plumes. J Volcanol Geotherm Res 1998; 87: 55-74.

[14] Cotton WR, Anthes RA. Storms and cloud dynamics. San Diego: Academic Press, Inc. 1989; p. 883.

[15] Lohmann U, Feichter J. Global indirect aerosol effects: a review. Atmos Chem Phys 2005; 5: 715-37.

[16] Sassen K, O'Starr C, Mace GG, et al. The 5-6 December 1991 FIRE IFO II jet stream cirrus case study: Possible influences of volcanic aerosols. J Atmos Sci 1995; 52: 97-123.

[17] Robock A. Stratospheric control of climate. Science 1996; 272 : 972-73.
[18] Robock A. Volcanic eruptions and climate. Rev Geophys 2000; 38: 191-219.

[19] Robock A. A latitudinally dependent volcanic dust veil index, and its effect on climate simulations. J Volcanol Geotherm Res 1981; 11: 67-80.

[20] Soden BJ, Wetherald RT, Stenchikov GL, Robock A. Global cooling after the eruption of Mount Pinatubo: a test of climate feedback by water vapor. Science 2002; 296: 727-30.

[21] Tupper A, Oswalt JS, Rosenfeld D. Satellite and radar analysis of the volcanic-cumulonimbi at Mount Pinatubo, Philippines, 1991. J Geophys Res 2005; 110: D09204.

[22] Textor C, Graf HF, Longo A, et al. Numerical simulation of explosive volcanic eruptions from the conduit flow to global atmospheric scales. Ann Geosphs 2005; 48: 817-42.

[23] Neri A, Macedonio G, Gidaspow D, Esposti Ongaro T. Multiparticle simulation of collapsing volcanic columns and pyroclastic flows. J Geophys Res 2003; 108, B4:2202.

[24] Herzog M, Oberhuber JM, Graf HF. A prognostic turbulence scheme for the nonhydrostatic plume model ATHAM. J Atmos Sci 2003; 60: 2783-96.

[25] Sassen K, Zhu J, Webley P, Dean K, Cobb P. Volcanic ash plume identification using polarization lidar: Augustine eruption, Alaska. Geophys Res Lett 2007; 34: L08803.

[26] Robock A. Volcanoes: role in climate. In: Encyclopedia of Atmospheric Sciences. In: Holton J, Curry JA, Pyle J, Eds. London: Academic Press 2003; pp. 2494-500.

[27] Oman L, Robock A, Stenchikov GL, Thordarson T. High-latitude eruptions cast shadow over the African monsoon and the flow of the Nile. Geophys Res Lett 2006; 33: L18711.

[28] Oman L, Robock A, Stenchikov GL, et al. Modeling the distribution of the volcanic aerosol cloud from the 1783-1784 Laki eruption. J Geophys Res 2006; 111: D12209.

[29] Houghton JT, Jenkins TJ, Ephraums JJ, Eds. Climate change: the IPCC scientific assessment. Cambridge, New York: Cambridge University Press 1990.

[30] Mölders N, Olson MA. Impact of urban effects on precipitation in high latitudes. J Hydrometeor 2004; 5: 409-29.

[31] $\mathrm{Li} \mathrm{Z}$, Bhatt US, Mölders N. Impact of doubled $\mathrm{CO}_{2}$ on the interaction between the global and regional water cycles in four study regions. Climate Dyn 2008; 30: 255-75.

[32] Power JA, Nye CJ, Coombs ML, et al. The reawakening of Alaska's Augustine volcano. Eos 2006; 87: 373-77.

[33] Casadevall TJ. The 1989-1990 eruption of Redoubt Volcano, Alaska: impacts on aircraft operations. J Volcanol Geotherm Res 1994; 62: 301-16.

[34] Skamarock WC, Klemp JB, Dudhia J, et al. A description of the advanced research WRF version 2. NCAR/TN-468+STR 2005; pp. 88 .

[35] Kuhn M, Builtjes PJH, Poppe D, et al. Intercomparison of the gasphase chemistry in several chemistry and transport models. Atmos Environ 1998; 32: 693-709.

[36] Thompson G, Rasmussen RM, Manning K. Explicit forecasts of winter precipitation using an improved bulk microphysics scheme. Part I: Description and sensitivity analysis. Mon Wea Rev 2004; 132: $519-42$

[37] Grell GA, Dévényi D. A generalized approach to parameterizing convection combining ensemble and data assimilation techniques. Geophys Res Lett 2002; 29(14), Article 1693.

[38] Hong SY, Pan HL. Nonlocal boundary layer vertical diffusion in a medium-range forecast model. Mon Wea Rev 1996; 124: 2322-39.

[39] Mlawer EJ, Taubman SJ, Brown PD, Iacono MJ, Clough SA Radiative transfer for inhomogeneous atmosphere: RRTM, a validated correlated-k model for the longwave. J Geophys Res 1997; 102 (D14): 16663-82.

[40] Dudhia J. Numerical study of convection observed during the winter monsoon experiment using a mesoscale two-dimensional model. J Atmos Sci 1989; 46: 3077-107.

[41] Smirnova TG, Brown JM, Benjamin SG. Performance of different soil model configurations in simulating ground surface temperature and surface fluxes. Mon Wea Rev 1997; 125: 1870-84.

[42] Smirnova TG, Brown JM, Benjamin SG, Kim D. Parameterization of cold season processes in the MAPS land-surface scheme. J Geophys Res 2000; 105 (D3): 4077-86.

[43] Mölders N. Suitability of the weather research and forecasting (WRF) model to predict the June 2005 fire weather for Interior Alaska. Wea Forecast 2008; 23: 953-73. 
[44] Wadge G. Output rate of magma from active central volcanoes. Nature 1980; 288: 253-55.

[45] Kramm G, Meixner FX. On the dispersion of trace species in the atmospheric boundary layer: a re-formulation of the governing equations for the turbulent flow of the compressible atmosphere. Tellus 2000; 52A: 500-22.

[46] Tetzlaff G, Dlugi R, Friedrich K, et al. On modeling dry deposition of long-lived and chemically reactive species over heterogeneous terrain. J Atm Chem 2002; 42: 123-55.

[47] Stith JL, Hobbs PV, Radke LF. Airborne particle and gas measurements in the emissions from six volcanoes. J Geophys Res 1978; 83: 4009-17.

[48] Swanson SE, Kienle J. The 1986 eruption of Mount St. Augustine: field test of a hazard evaluation. J Geophys Res1988; 93: 4500-20.

[49] Woods AW, Kienle J. The injection of volcanic ash into the atmosphere. In: Casadevall, TJ, Ed. Volcanic ash and aviation safety: proceedings of the first international symposium on volcanic ash and aviation safety, U.S. Geological Survey Bulletin B 2047. 1994; 101-06.

[50] Hobbs PV, Radke LF, Lyons JH, Ferek RJ, Coffman DJ, Casadevall TJ. Airborne measurements of particle and gas emissions from the 1990 volcanic eruptions of Mount Redoubt. J Geophys Res 1991; 96: 735-52.

[51] Hobbs PV, Tuell JP, Hegg DA, Radke LF, Eltgroth MW. Particles and gases in the emissions from the 1980-1981 volcanic eruptions of Mt. St. Helens. J Geophys Res 1982; 87: 11062-86.

[52] Mather TA, Pyle DM, Oppenheimer C. Tropospheric volcanic aerosol. Volcanism and the Earth's atmosphere, Geophys Am Geophys Union 2003; 139: 189-212.

[53] Wallace K. Personal Communication 2006.

[54] Anthes RA. Regional models of the atmosphere in middle latitudes. Mon Wea Rev 1983; 111: 1306-35.

[55] Anthes RA, Kuo YH, Hsie EY, Low-Nam S, Bettge TW. Estimation of skill and uncertainty in regional numerical models. Quart J Roy Meteorol Soc 1989; 111: 763-806.

[56] Von Storch H, Zwiers FW. Statistical analysis in climate research. UK: Cambridge University Press 1999; p. 484.

[57] Shulski M, Wendler G. The climate of Alaska. Fairbanks: University Alaska Press 2007; p. 216.

[58] Montgomery DC. Design and Analysis of Experiments. $3^{\text {rd }}$ ed. New York; Wiley and Sons 1976.

[59] Zwiers FW. Interannual variability and predictability in an ensemble of AMIP climate simulations conducted with the CCC GCM2. Clim Dyn 1996; 12: 825-47.

[60] Rowell DP. Assessing potential seasonal predictability with an ensemble of multidecadal GCM simulations. J Climate 1998; 11: 109-20.

[61] Zwiers FW, Weaver AJ. The causes of $20^{\text {th }}$ century warming. Science 2000; 290 (5499): 2081.

[62] Zhao M, Pitman AJ, Chase TN. Climatic impact of land-cover changes at different carbon dioxide levels. Clim Res 2001; 17: 118.

[63] Caires S, Swail VR, Wang XL. Projection and analysis of extreme wave climate. J Climate 2003; 19: 5581-605.

[64] Wang XL, Swail VR. Climate change signal and uncertainty in projections of ocean wave heights, Clim Dyn 2006: 26, 109-26.
[65] Li Z, Mölders N. Interaction of impacts of doubling $\mathrm{CO}_{2}$ and changing regional land-cover on evaporation, precipitation, and runoff at global and regional scales. Int J Climatol 2008; 28: 165379.

[66] Skamarock WC. Evaluating mesoscale NWP models using kinetic energy spectra. Mon Wea Rev 2004; 132: 3019-32.

[67] Cheng WYY, Steenburgh WJ. Evaluation of surface sensible weather forecasts by the WRF and the Eta models over the western United States. Wea Forecast 2005; 20: 812-21.

[68] Grell GA, Peckham SE, Schmitz R, et al. Fully coupled "online" chemistry within the WRF model. Atmos Environ 2005; 39: 695775 .

[69] Davis C, Brown B, Bullock R. Object-based verification of precipitation forecasts. Part I: Methodology and application to mesoscale rain areas. Mon Wea Rev 2006; 134: 1772-84.

[70] Davis C, Wang W, Chen SS, et al. Prediction of landfalling hurricanes with the advanced hurricane WRF model. Mon Wea Rev 2008; 136: 1990-2005.

[71] Hines KM, Bromwich DH. Development and testing of polar weather research and forecasting (WRF) model. Part I: Greenland Ice Sheet meteorology. Mon Wea Rev 2008; 136: 1971-89.

[72] Mölders N, Kramm G. A case study on wintertime inversions in Interior Alaska with WRF. Atmos Res 2009; doi.org/10.1016/ j.atmosres.2009.06.002.

[73] Grell GA, Dudhia J, Stauffer DR. A description of the fifth generation Penn State/NCAR mesoscale model (MM5). NCAR Tech Note NCAR/TN-398+STR 1995; p. 138. [Available from NCAR Publications Office, P.O. Box 3000, Boulder, CO 80307 3000].

[74] Bromwich DH, Cassano JJ, Klein T, et al. Mesoscale modeling of katabatic winds over Greenland with the Polar MM5. Mon Wea Rev 2001; 129: 2290-309.

[75] Nutter PA, Manobianco J. Evaluation of the $29 \mathrm{~km}$-Eta Model. Part I: Objective verification at three selected stations. Wea Forecast 1999; 14: 5-17

[76] Zhong S, In H, Bian X, Charney J, Heilman W, Potter B. Evaluation of real-time high resolution MM5 predictions over the Great Lakes region. Wea Forecast 2005; 20: 63-81.

[77] PaiMazumder D, Mölders N. Theoretical assessment of uncertainty in regional averages due to network density and design. J Appl Meteor Clim 2009; 48: 1643-66.

[78] Yang D, Kane DL, Hinzman LD, et al. An evaluation of the Wyoming gauge system for snowfall measurement. Water Resources Res 2000; 36: 2665-77.

[79] Sugiura K, Yang D. Systematic error aspects of gauge-measured solid precipitation in the Arctic, Barrow, Alaska. Geophys Res Lett 2003; 4: 1192.

[80] Mölders N, Laube M, Raschke E. Evaluation of model generated cloud cover by means of satellite data. Atmos Res 1995; 39: 91111.

[81] Mölders N, Kramm G. Influence of wildfire induced land-cover changes on clouds and precipitation in Interior Alaska - A case study. Atmos Res 2007; 84: 142-68.

[82] Simpson JJ, Hufford GL, Pieri D, Berg J. Failures in detecting volcanic ash from a satellite-based technique. Remote Sens Environ 2000; 72: 191-217. 